\title{
Transmission Line Environmental Assessment Guidance Document
}

by J. Jackson, * E. Pentecost, and J. Muzzarelli

Environmental Assessment Division,

Argonne National Laboratory, 9700 South Cass Avenue, Argonne, Illinois 60439

January 1994

Work sponsored by United States Department of Energy, Office of Fuels Programs

JJackson is affiliated with Argonne's Decision and Information Sciences Division. 


\section{CONTENTS}

ACKNOWLEDGMENTS $\ldots \ldots \ldots \ldots \ldots \ldots \ldots \ldots \ldots \ldots \ldots \ldots$

NOTATION $\ldots \ldots \ldots \ldots \ldots \ldots \ldots \ldots \ldots \ldots \ldots \ldots \ldots \ldots \ldots \ldots \ldots$ vii

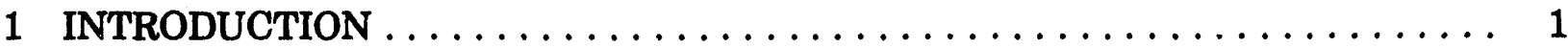

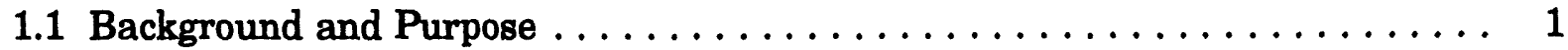

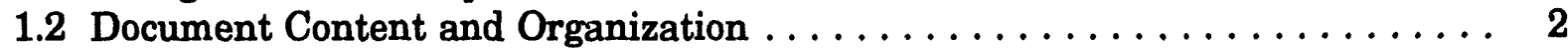

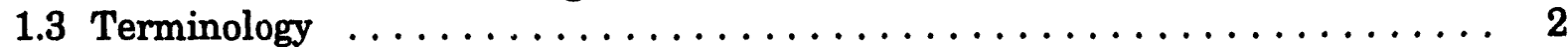

2 LEGISLATION, PERMITS, AND CONSULTATION $\ldots \ldots \ldots \ldots \ldots \ldots$

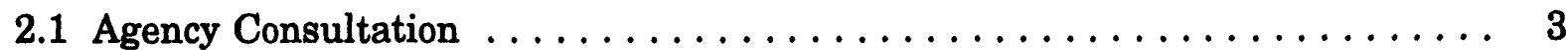

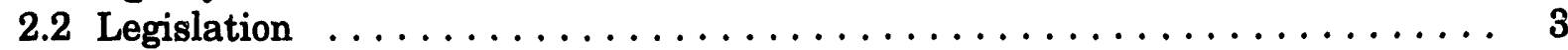

2.3 Permit Requirements $\ldots \ldots \ldots \ldots \ldots \ldots \ldots \ldots \ldots \ldots \ldots \ldots$

3 POTENTIAL IMPACT ISSUES AND CORRESPONDING DATA NEEDS $\ldots \ldots$. . 11

3.1 Transmission Line Design Factors $\ldots \ldots \ldots \ldots \ldots \ldots \ldots \ldots \ldots \ldots$

3.1 .1 Potential Impact Issues $\ldots \ldots \ldots \ldots \ldots \ldots \ldots \ldots \ldots \ldots \ldots \ldots \ldots$

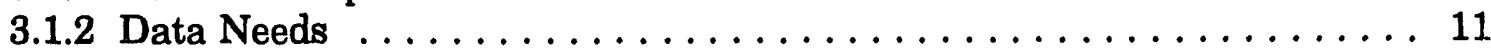

3.2 Baseline Information on the Affected Environment $\ldots \ldots \ldots \ldots \ldots \ldots \ldots$

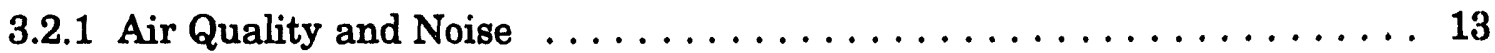

3.2.1.1 Potential Impact Issues $\ldots \ldots \ldots \ldots \ldots \ldots \ldots \ldots \ldots \ldots$

3.2.1.2 Data Needs ... . . . . . . . . . . . . . . . . . . . 15

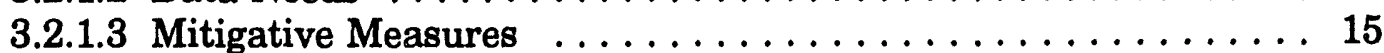

3.2 .2 Biotic Resources . . . . . . . . . . . . . . . . . . . 16

3.2.2.1 Potential Impact Issues $\ldots \ldots \ldots \ldots \ldots \ldots \ldots \ldots \ldots \ldots$

3.2.2.2 Data Needs . . . . . . . . . . . . . . . . . . . . . . 19

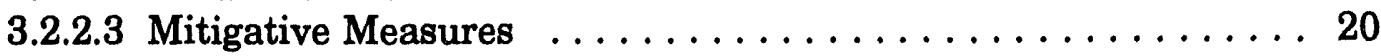

3.2 .3 Cultural Resources . . . . . . . . . . . . . . . . . . 23

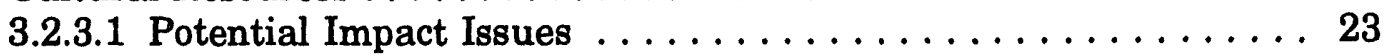

3.2.3.2 Data Needs .......................... 24

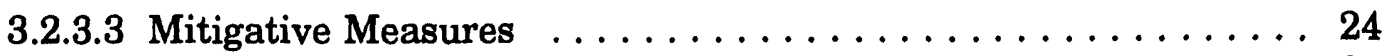

3.2 .4 Land Use . . . . . . . . . . . . . . . . . . . . 26

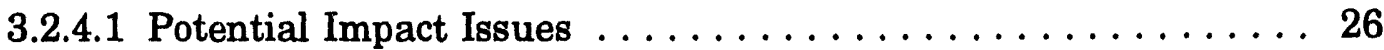

3.2.4.2 Data Needs ......................... 27

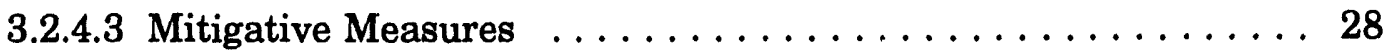

3.2 .5 Geology and Soils . . . . . . . . . . . . . . . . . . . . 29

3.2.5.1 Potential Impact Issues . . . . . . . . . . . . . . 29

3.2.5.2 Data Needs . . . . . . . . . . . . . . . . . . . 30

3.2.5.3 Mitigative Measures $\ldots \ldots \ldots \ldots \ldots \ldots \ldots \ldots \ldots \ldots$

3.2 .6 Socioeconomics . . . . . . . . . . . . . . . . . . . . 31

3.2.6.1 Potential Impact Issues $\ldots \ldots \ldots \ldots \ldots \ldots \ldots \ldots \ldots \ldots$

3.2.6.2 Data Needs . . . . . . . . . . . . . . . . . . . . 32

3.2.6.3 Mitigative Measures $\ldots \ldots \ldots \ldots \ldots \ldots \ldots \ldots \ldots \ldots$ 


\section{CONTENTS (Cont.)}

3.2.7 Water Resources $\ldots \ldots \ldots \ldots \ldots \ldots \ldots \ldots \ldots \ldots \ldots \ldots \ldots, \ldots \ldots$

3.2.7.1 Potential Impact Issues $\ldots \ldots \ldots \ldots \ldots \ldots \ldots \ldots \ldots \ldots, 33$

3.2.7.2 Data Needs ......................... 34

3.2.7.3 Mitigative Measures $\ldots \ldots \ldots \ldots \ldots \ldots \ldots \ldots \ldots \ldots, 34$

3.2.8 Visual Resources $\ldots \ldots \ldots \ldots \ldots \ldots \ldots \ldots \ldots \ldots \ldots \ldots \ldots, 34$

3.2.8.1 Potential Impact Issues $\ldots \ldots \ldots \ldots \ldots \ldots \ldots \ldots \ldots \ldots, 34$

3.2.8.2 Data Needs ......................... 35

3.2.8.3 Mitigative Measures $\ldots \ldots \ldots \ldots \ldots \ldots \ldots \ldots \ldots \ldots, 36$

3.2.9 Health and Safety $\ldots \ldots \ldots \ldots \ldots \ldots \ldots \ldots \ldots \ldots \ldots \ldots \ldots \ldots, \ldots \ldots \ldots$

3.2.9.1 Potential Impact Issues $\ldots \ldots \ldots \ldots \ldots \ldots \ldots \ldots \ldots \ldots, \ldots \ldots$

3.2.9.2 Data Needs $\ldots \ldots \ldots \ldots \ldots \ldots \ldots \ldots \ldots \ldots \ldots, \ldots \ldots$

3.2.9.3 Mitigative Measures $\ldots \ldots \ldots \ldots \ldots \ldots \ldots \ldots \ldots \ldots, 40$

APPENDIX A: Overview of the National Environmental Policy Act and DOE Implementing Procedures $\ldots \ldots \ldots \ldots \ldots \ldots \ldots \ldots, 43$

APPENDIX B: Legislation Applicable to Transmission Line Projects . . . . . . . . 53

REFERENCES $\ldots \ldots \ldots \ldots \ldots \ldots \ldots \ldots \ldots \ldots \ldots \ldots \ldots \ldots \ldots \ldots$

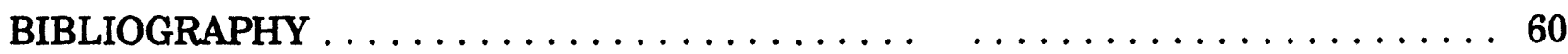

\section{TABLES}

2.1 Agencies with Whom Consultation Is Required by Law $\ldots \ldots \ldots \ldots \ldots$

2.2 Possible Transmission Line Project Actions Subject to Environmental Protection Statutes $\ldots \ldots \ldots \ldots \ldots \ldots \ldots \ldots \ldots \ldots \ldots, \ldots$

2.3 Federal, State, and Local Permit Requirements ................. 9

A.1 Examples of DOE Projects that Require Different Levels of NEPA Documentation ................................. 46

A.2 Example of an Environmental Assessment Outline for Transmission Line Interconnection Project $\ldots \ldots \ldots \ldots \ldots \ldots \ldots \ldots \ldots \ldots \ldots \ldots$

A.3 Example of an EIS Outline for Transmission Line Interconnection Project . . . . 49 


\section{FIGURES}

2.1 Overview of Project Planning Meeting $\ldots \ldots \ldots \ldots \ldots \ldots \ldots$

3.1 Generalized Impact Assessment Process with Ecological Resources

Used as an Example . . . . . . . . . . . . . . . . . . . . . 13

3.2 Air Quality and Noise Impact Assessment Issues and Data Needs $\ldots \ldots \ldots$

3.3 Biotic Resources Impact Assessment Issues and Data Needs . . . . . . . . . . . 17

3.4 Cultural Resources Impact Assessment Issues and Data Needs . . . . . . . . . . 25

3.5 Land Use Impact Assessment Issues and Data Needs . . . . . . . . . . . . . . 27

3.6 Geology and Soils Impact Assessment Issues and Data Needs . . . . . . . . . . 30

3.7 Socioeconomic Impact Assessment Issues and Data Needs . . . . . . . . . . . . 32

3.8 Water Resources Impact Assessment Issues and Data Needs . . . . . . . . . . . 35

3.9 Visual Resources Impact Assessment Issues and Data Needs . . . . . . . . . 36

3.10 Health and Safety Impact Issues and Data Needs $\ldots \ldots \ldots \ldots \ldots$

A.1 Overview of DOE NEPA Decision-Making and Documentation Process . . . . . 45 


\section{ACKNOWLEDGMENTS}

We wish to express our thanks to the U.S. Department of Energy, Office of Fossil Energy, for funding this project. Leadership for this project has been provided by DOE program manager Anthony Como.

We also wish to thank our colleagues at Argonne for their contributions: William Vinikour and Shirley Neitzel for their technical reviews and comments; John DePue and Margaret Ortigara for their editorial assistance; and Michele Szawars for her assistance in preparing graphics. 


\section{NOTATION}

The following is a list of the principal abbreviations, acronyms, and symbols (including units of measure) used in this report.

\section{ACRONYMS, INITIALISMS, AND ABBREVIATIONS}

\begin{tabular}{|c|c|}
\hline $\mathbf{A C}$ & alternating current \\
\hline CEQ & Council on Environmental Quality \\
\hline CFR & Code of Federal Regulations \\
\hline CZMA & Coastal Zone Management Act \\
\hline $\mathrm{DC}$ & direct current \\
\hline DOE & U.S. Department of Energy \\
\hline EA & environmental assessment \\
\hline EIS & environmental impact statement \\
\hline EMF & electric and magnetic fields \\
\hline ER & environmental report \\
\hline ESA & Endangered Species Act \\
\hline FONSI & finding of no significant impact \\
\hline FR & Federal Register \\
\hline FWS & U.S. Fish and Wildlife Service \\
\hline NEPA & National Environmental Policy Act of 1969 \\
\hline NPDES & National Pollutant Discharge Elimination System \\
\hline OD & Becision \\
\hline
\end{tabular}

\section{UNITS OF MEASURE}

$\begin{array}{ll}\mathrm{ft} & \text { foot (feet) } \\ \mathrm{in} . & \text { inch(es) } \\ \mathrm{kV} & \text { kilovolt(s) } \\ \mathrm{m} & \text { meter(s) } \\ \mathrm{mi} & \text { mile(s) }\end{array}$




\title{
TRANSMISSION LINE ENVIRONMENTAL ASSESSMENT GUIDANCE DOCUMENT
}

\author{
by \\ J. Jackson, E. Pentecost, and J. Muzzarelli
}

\section{INTRODUCTION}

\subsection{BACKGROUND AND PURPOSE}

Since 1939 , U.S. utility companies have been required to obtain a Presidential Permit to construct electric transmission lines that cross a U.S. border and connect with a foreign utility. Issuance of these permits has been a function of the U.S. Department of Energy (DOE) since 1977. Within DOE, the authority to issue these permits and to authorize exports of electric energy is held by the Deputy Assistant Secretary for Fuels Programs (Federal Register [FR], Vol. 54, No. 52, March 20, 1989, pp. 11436-11438) (DOE 1989).

Before issuing a new Presidential Permit or authorizing modification of an existing one, DOE must fully assess the potential environmental impacts of the proposed action, as set forth by the National Environmental Policy Act of 1969 (NEPA). In general, the environmental impacts referred to here are those resulting from actions occurring within the United States. Depending on the nature and scope of the proposed project, either an environmental assessment (EA) or environmental impact statement (EIS) will be prepared (see Appendix A). Currently, DOE regulations (Title 10, Code of Federal Regulations [CFR], Subpart W, Parts 205.328-205.329) allow the utility to prepare a draft of the appropriate NEPA document or to request that DOE prepare the document. Typically, DOE will issue an impact assessment document that identifies the anticipated environmental impacts associated with project construction, transmission line operation, and right-of-way maintenance.

To prepare the draft NEPA document or to provide DOE with the information needed to do so, utility companies (applicants) applying for a new permit or modification of an existing one must be familiar with applicable environmental laws and regulations and must compile background information on project design, the potentially affected environment, locations of proposed and alternative transmission line routes and of other system components, proposed operation modes, and proposed maintenance schedules and practices. It is important to note that NEPA requires that the environmental data presented for alternatives to the proposed action be at the same level of detail as the data presented for the proposed action.

The purpose of this document is to provide Presidential Permit applicants with two types of guidance: (1) on the type of environmental and project descriptive information 
needed to assess the potential impacts of the proposed and alternative actions and (2) on compliance with applicable federal and state regulations.

\subsection{DOCUMENT CONTENT AND ORGANIZATION}

This document contains text and graphics intended to guide Presidential Permit applicants in assessing the environmental impacts of proposed actions or in compiling the data that would be needed by others assessing those impacts. The three main chapters present information on the purpose and content of this document (Chapter 1); legislative, regulatory, and consultation requirements for transmission line interconnect projects (Chapter 2); and identification of basic transmission system design parameters and environmental data requirements for analysis of potential impacts of the proposed action (Chapter 3). Chapter 3 also includes information on possible techniques or measures to mitigate impacts. In some subsections of Chapter 3 , additional guidance is included on the scope and analyses of impacts appropriate for inclusion in the NEPA document.

Appendix A presents an overview of NEPA requirements and DOE's implementing procedures, as well as examples of EA and EIS outlines. Appendix B summarizes information on legislation that may be applicable to transmission line projects proposed in Presidential Permit applications. Two sections follow the appendixes. "References" lists all cited documents; the published sources cited in the Bibliography present additional information on environmental data, mitigation techniques, and good engineering practices. The list is not inclusive and should be considered only as a starting point for compiling environmental and design information.

\subsection{TERMINOLOGY}

For ease of presentation, generic terms have been used in the discussion of broad topics throughout the document. For example, the term "stream" is used to mean any intermittent or perennial stream or river. The term "right-of-way" is used in a generic sense to mean the proposed routes and alternative routes for the proposed transmission line. In a NEPA document, "preferred route" and "proposed route" are synonymous with the term "preferred alternative." 


\section{LEGISLATION, PERMITS, AND CONSULTATION}

This chapter outlines agency consultations, legislation, and permits applicable to construction, operation, and maintenance of electric transmission lines requiring Presidential Permits. The types of information required for evaluation of impacts are often detailed in the permit and consultation process. Figure 2.1 shows the agencies that should be involved and issues that should be addressed at a preliminary planning meeting to develop information on the scope of the project.

\subsection{AGENCY CONSULTATION}

Before approving Presidential Permit applications, DOE may be required by statute or regulations to enter into either formal or informal consultations with other federal and state agencies. In addition, many federal and state agencies have some degree of responsibility for certain geographical areas or natural resources. Such agencies may have an interest in the preparation of the NEPA documents for a Presidential Permit and may be able to provide valuable input. As appropriate, DOE requests consultation with the agencies identified in Table 2.1. Formal and informal consultations with federal agencies are conducted independently by DOE for the NEPA documents prepared as part of the Presidential Permit process. Typically, however, the utility company provides technical information needed by DOE for the consultations. The utility company normally prepares an environmental report (ER) to fulfill state permit requirements. The ER is usually provided to DOE and serves as the support documentation for the Presidential Permit application.

\subsection{LEGISLATION}

Appendix B lists the spectrum of laws, regulations, executive orders, and statutes that must be considered before construction of an electric transmission line. In general, the listed measures concern managing and protecting a broad range of cultural, physical, and biological resources. Table 2.2 lists possible actions that are subject to federal environmental protection statutes.

\subsection{PERMIT REQUIREMENTS}

The principal permits, licenses, and approvals required for the construction and operation of an electric transmission line are listed in Table 2.3. The federal, state, and local

\footnotetext{
* This preliminary planning meeting should not be confused with the public scoping meetings that are held during the EIS process to give members of the public and government agencies the opportunity to submit formal comments on impact issues and project scope.
} 


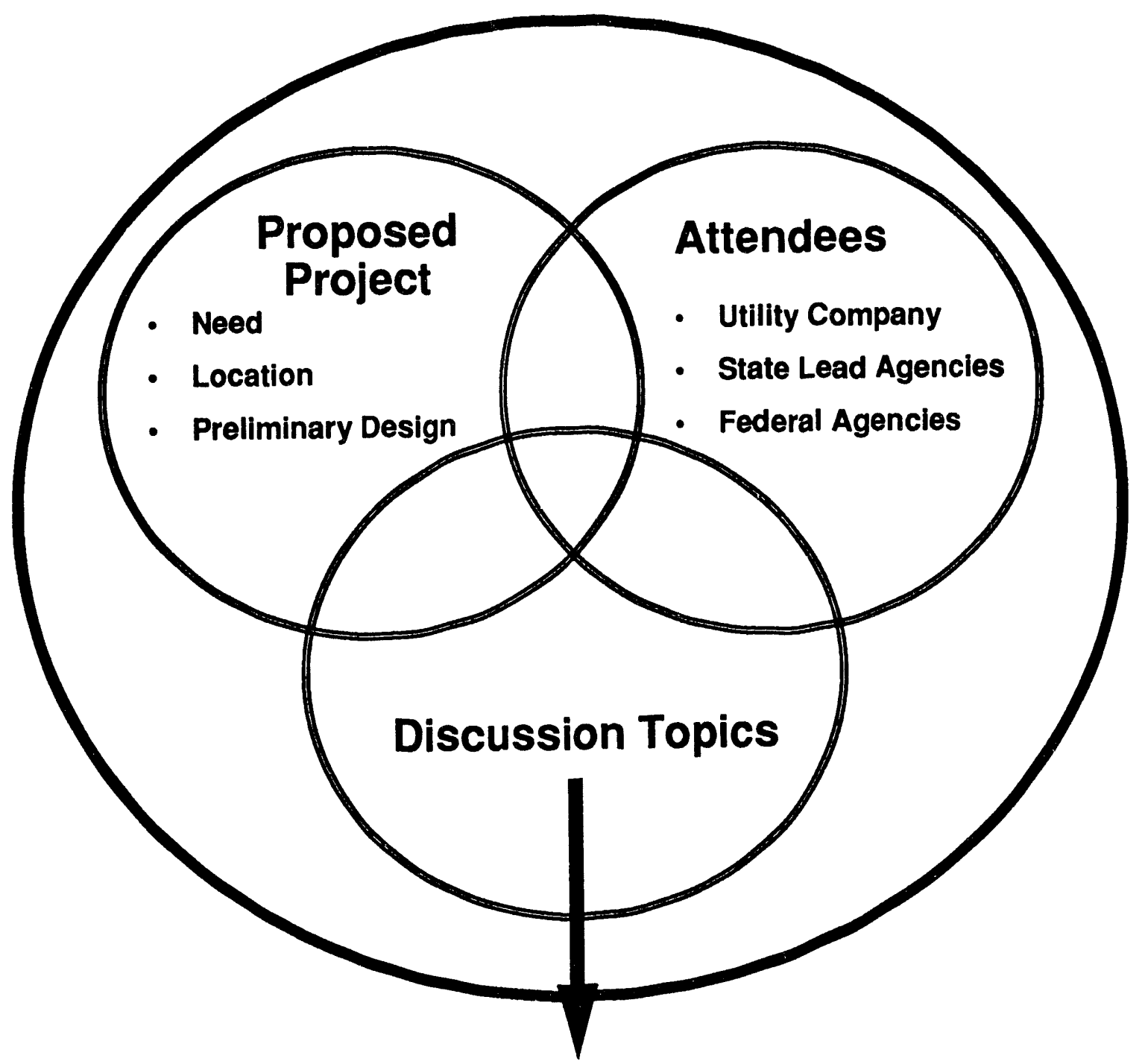

- Utility Siting Laws

- Environmental Documentation Requirements

- State Review Process (Certificates/Approvals)

- State's Electric/Magnetic Field Standards

- State Regulations on Power Line Design

- State/Federal Approvals for Projects in Floodplains, Wetlands, and Stream Crossings

- Compatibility with State and Local Government Plans

- State Air Quality and Noise Regulations

FIGURE 2.1 Overview of Project Planning Meeting 
TABLE 2.1 Agencies with Whom Consultation Is Required by Law

\begin{tabular}{|c|c|c|c|}
\hline Subject & Legislation $^{b}$ & Agency & $\begin{array}{c}\text { Nature of Action or } \\
\text { Consideration }\end{array}$ \\
\hline $\begin{array}{l}\text { Endangered } \\
\text { species }\end{array}$ & $\begin{array}{l}\text { Endangered Species } \\
\text { Act of } 1973 \text { as } \\
\text { amended, state laws }\end{array}$ & $\begin{array}{l}\text { U.S. Fish and } \\
\text { Wildlife Service, } \\
\text { state agencies }\end{array}$ & $\begin{array}{l}\text { Federal: Issue biological } \\
\text { opinion on threatened and } \\
\text { endangered species (Section 7); } \\
\text { State: Issue an opinion on } \\
\text { project impacts to state } \\
\text { threatened and endangered } \\
\text { species }\end{array}$ \\
\hline $\begin{array}{l}\text { Migratory } \\
\text { birds }\end{array}$ & $\begin{array}{l}\text { Migratory Bird Treaty } \\
\text { Act }\end{array}$ & $\begin{array}{l}\text { U.S. Fish and } \\
\text { Wildlife Service }\end{array}$ & $\begin{array}{l}\text { Consultation on ways to avoid } \\
\text { or minimize effects on } \\
\text { migratory birds }\end{array}$ \\
\hline $\begin{array}{l}\text { Bald and } \\
\text { golden } \\
\text { eagles }\end{array}$ & $\begin{array}{l}\text { Bald and Golden Eagle } \\
\text { Protection Act }\end{array}$ & $\begin{array}{l}\text { U.S. Fish and } \\
\text { Wildlife Service, } \\
\text { state fish and } \\
\text { wildlife agency }\end{array}$ & $\begin{array}{l}\text { Cunsultation on ways to avoid } \\
\text { or minimize effects on bald } \\
\text { and golden eagles }\end{array}$ \\
\hline $\begin{array}{l}\text { Historic } \\
\text { preservation }\end{array}$ & $\begin{array}{l}\text { Archaeological and } \\
\text { Historic Preservation } \\
\text { Act of } 1974, \\
\text { Archaeological } \\
\text { Resources Protection } \\
\text { Act of } 1979, \text { National } \\
\text { Historic Preservation } \\
\text { Act of } 1966\end{array}$ & $\begin{array}{l}\text { State Historic } \\
\text { Preservation Office, } \\
\text { President's } \\
\text { Advisory Council } \\
\text { on Historic } \\
\text { Preservation }\end{array}$ & $\begin{array}{l}\text { Issue cultural resource } \\
\text { clearance, required before } \\
\text { construction }\end{array}$ \\
\hline $\begin{array}{l}\text { American } \\
\text { Indian lands }\end{array}$ & $\begin{array}{l}\text { American Indian } \\
\text { Religious Freedom Act } \\
\text { as amended }\end{array}$ & $\begin{array}{l}\text { Potentially affected } \\
\text { Indian tribes }\end{array}$ & $\begin{array}{l}\text { Consultation to avoid } \\
\text { infringement on areas of } \\
\text { religious value to Native } \\
\text { American groups }\end{array}$ \\
\hline $\begin{array}{l}\text { Prime and } \\
\text { unique } \\
\text { farmlands }\end{array}$ & $\begin{array}{l}\text { Farmland Protection } \\
\text { Policy Act of } 1981 \text {, } \\
\text { Council on } \\
\text { Environmental Quality } \\
\text { Memo of August 20, } \\
1988\end{array}$ & $\begin{array}{l}\text { Soil Coriservation } \\
\text { Service, state or } \\
\text { local agencies }\end{array}$ & $\begin{array}{l}\text { Evaluate impacts to prime and } \\
\text { unique farmlands }\end{array}$ \\
\hline
\end{tabular}


TABLE 2.1 (Cont.)

\begin{tabular}{|c|c|c|c|}
\hline Subject & Legislation $^{\mathrm{b}}$ & Agency & $\begin{array}{c}\text { Nature of Action or } \\
\text { Consideration }\end{array}$ \\
\hline Floodplains & Executive Order 11988 & $\begin{array}{l}\text { Corps of Engineers, } \\
\text { state agencies }\end{array}$ & $\begin{array}{l}\text { Evaluate potential floodplain } \\
\text { effects }\end{array}$ \\
\hline Wetlands & Executive Order 11990 & $\begin{array}{l}\text { Corps of Engineers, } \\
\text { state agencies }\end{array}$ & $\begin{array}{l}\text { Evaluate potential effects on } \\
\text { wetlands }\end{array}$ \\
\hline Coastal zone & $\begin{array}{l}\text { Coastal Zone } \\
\text { Management Act of } \\
1972 \text { as amended }\end{array}$ & $\begin{array}{l}\text { National Oceanic } \\
\text { and Atmospheric } \\
\text { Administration }\end{array}$ & $\begin{array}{l}\text { Evaluate likely effects to the } \\
\text { coastal zone }\end{array}$ \\
\hline $\begin{array}{l}\text { Water-body } \\
\text { alteration }\end{array}$ & $\begin{array}{l}\text { Fish and Wildlife } \\
\text { Coordination Act }\end{array}$ & $\begin{array}{l}\text { U.S. Fish and } \\
\text { Wildlife Service, } \\
\text { state agencies }\end{array}$ & $\begin{array}{l}\text { Consultation regarding } \\
\text { impounding, diverting, or } \\
\text { controlling waters in excess of } \\
10 \text { acres in surface area }\end{array}$ \\
\hline $\begin{array}{l}\text { Water } \\
\text { pollution }\end{array}$ & Clean Water Act & $\begin{array}{l}\text { U.S. Environmental } \\
\text { Protection Agency, } \\
\text { state agencies }\end{array}$ & $\begin{array}{l}\text { Evaluate impacts to water } \\
\text { quality, water use, and } \\
\text { drinking water standards }\end{array}$ \\
\hline $\begin{array}{l}\text { Water use } \\
\text { and } \\
\text { availability }\end{array}$ & $\begin{array}{l}\text { Water Resources } \\
\text { Planning Act of } 1965 \text {, } \\
\text { Safe Drinking Water } \\
\text { Act, other's }\end{array}$ & $\begin{array}{l}\text { Office of Water } \\
\text { Policy, state } \\
\text { agencies }\end{array}$ & $\begin{array}{l}\text { Evaluate impacts to water } \\
\text { quality, use, and drinking } \\
\text { water standards }\end{array}$ \\
\hline Soils & $\begin{array}{l}\text { Soil and Water } \\
\text { Resources Conservation } \\
\text { Act of } 1977\end{array}$ & $\begin{array}{l}\text { Soil Conservation } \\
\text { Service }\end{array}$ & $\begin{array}{l}\text { Evaluate erosion impacts, loss } \\
\text { in land and water productivity }\end{array}$ \\
\hline Air & $\begin{array}{l}\text { Clean Air Act as } \\
\text { amended }\end{array}$ & $\begin{array}{l}\text { U.S. Environmental } \\
\text { Protection Agency, } \\
\text { state agencies }\end{array}$ & $\begin{array}{l}\text { Evaluate impact of air quality } \\
\text { on public health }\end{array}$ \\
\hline Noise & $\begin{array}{l}\text { Noise Control Act of } \\
1972\end{array}$ & $\begin{array}{l}\text { U.S. Environmental } \\
\text { Protection Agency }\end{array}$ & $\begin{array}{l}\text { Evaluate impact of noise } \\
\text { emissions from associated } \\
\text { construction and } \\
\text { transportation equipment }\end{array}$ \\
\hline
\end{tabular}


TABLE 2.1 (Cont.)

\begin{tabular}{llll}
\hline Subject & \multicolumn{1}{c}{ Legislation $^{\mathrm{b}}$} & \multicolumn{1}{c}{ Agency } & \multicolumn{1}{c}{$\begin{array}{c}\text { Nature of Action or } \\
\text { Consideration }\end{array}$} \\
\hline $\begin{array}{l}\text { Siting and } \\
\text { planning }\end{array}$ & $\begin{array}{l}\text { State siting acts, } \\
\text { county zoning } \\
\text { regulations }\end{array}$ & $\begin{array}{l}\text { State and county } \\
\text { agencies }\end{array}$ & $\begin{array}{l}\text { Evaluate route selection and } \\
\text { right-of-way considerations }\end{array}$ \\
Solid wastes & $\begin{array}{l}\text { Resource Conservation } \\
\text { and Recovery Act }\end{array}$ & $\begin{array}{l}\text { U.S. Environmental } \\
\text { Protection Agency, } \\
\text { state agencies }\end{array}$ & $\begin{array}{l}\text { Evaluate waste disposal at } \\
\text { operating facilities }\end{array}$ \\
\hline
\end{tabular}

a Consultations actually required for a specific project would depend on the characteristics of that site.

b Only federal legislation and executive orders mandating consultation are specifically listed; state requirements would vary but in many cases would be similar in scope.

agencies responsible for each action are also identified. As part of the process of receiving agency permit approvals, the applicant must comply with various standard requirements. Not all of the permits listed in the table apply in all cases, and the list is not necessarily complete for all locations. The final EIS for the Washington Water Power/BC Hydro Transmission Interconnection Project provides a good example of project permit requirements (DOE 1992a).

In addition to the need to comply with federal permit requirements and regulations, the applicant must also adhere to applicable terms of the appropriate state pollution control programs, planning measures, permits, and regulations. The applicant should contact the appropriate agencies of each state to obtain information on existing state regulations with which electric utilities must comply in constructing and operating an electric transmission line. Table 2.3 lists the general types of state and local agencies with environmental protection responsibilities; however, the specific names of the agencies vary by state. A valuable reference to use in identifying specific agencies responsible for resource management and protection is the Conservation Directory (Gordon 1993), which is available from the National Wildlife Federation, Washington, D.C. When contacting any of the responsible state and local agencies, the applicant should address the following topics:

1. State requirements for preparing an EA, EIS, or environmental impact report;

2. Certificates required for project construction and operation (e.g., Certificate of Environmental Compatibility, Certificate of Convenience and Necessity); 
TABLE 2.2 Possible Transmission Line Project Actions Subject to Environmental Protection Statutes

Possible Action

Impact air quality

Release dust to the atmosphere

Impact water quality

Clear land or establish hard surfaces

Discharge wastewaters into surface water or groundwater

Handle hazardous materials

Store, handle, transport, or dispose of hazardous wastes

Spill hazardous wastes or chemicals

Transport hazardous wastes or chemicals

Undertake any activities near a coast

Undertake any activities within a floodplain

Undertake any activities within a wetland

Undertake any activities on prime or unique farmland

Undertake any activities on federal land

Undertake activities near a remote river

Generate noise

Impact native plants and animals

\author{
Federal Statute
}

Clean Water Act; Safe Drinking Water Act; National Ocean Pollution Planning Act

Resource Conservation and Recovery Act;

Toxic Substance Control Act;

Federal Insecticide, Fungicide, and

Rodenticide Act

Hazardous Material Transportation Act, as amended by Hazardous Material Transportation Uniform Safety Act

Coastal Zone Management Act

Executive Order 11988

Executive Order 11990

Farmland Protection Policy Act; Council on Environmental Quality Memo of August 20, 1980

Federal Land Policy and Management Act

Wild and Scenic Rivers Act

Noise Control Act

Endangered Species Act; Fish and Wildlife Coordination Act; Bald and Golden Eagle Protection Act; Migratory Bird Treaty Act; Marine Mammal Protection Act 
TABLE 2.3 Federal, State, and Local Permit Requirements ${ }^{a}$

Agency

Nature of Action or Consideration

Federal Agencies

Department of Energy, Assistant

Secretary for Fossil Energy

Department of the Interior, Bureau of Land Management

Department of the Interior, Bureau of Indian Affairs

Department of the Interior, Fish and Wildlife Service

Department of Defense, Corps of Engineers

Department of Transportation, Federal Aviation Administration

Department of Transportation, Federal Highway Administration

Occupational Safety and Health Administration

Indian Agencies ${ }^{\mathrm{b}}$ Indian Tribal Business Council

State Agencies ${ }^{\mathrm{b}}$

Department of Wildlife
Issue Presidential Permit (only necessary to construct, connect, operate, and maintain facilities that cross an international border of the United States)

Issue right-of-way permit for construction of access facilities across federal lands

Issue temporary use permit(s)

Consultation regarding construction within Indian Reservation boundaries

Issue biological opinion on threatened or endangered species (Section 7 of the Endangered Species Act) for all federal actions

Issue nationwide or individual permit(s) (Section 404 of the Clean Water Act) for placement of dredged or fill material in waters of the United States or their adjacent wetlands

Issue permit(s) (Section 10 of the River and Harbor Act) for structures affecting navigable waters of the United States

Determination of "no hazard" (notice of proposed construction or alteration)

Issue permit(s) to cross federal-aid highways

Issue permit for occupational safety and health during construction, operation, and maintenance activities

Issue permit(s) to cross Indian reservation lands

Issue biological opinion on state rare or endangered wildlife species

Issue permit(s) to modify state water projects

Issue debris or slash burning permit(s) 
TABLE 2.3 (Cont.)

Agency

Department of Natural Resources

Public Utility Commission

Department of Transportation

State Historic Preservation Office

\section{Local Agencies ${ }^{b}$}

Local towns, cities, counties, municipalities, boroughs, planning commissic as, etc.
Issue permit(s) for construction on state-owned land

Issue utility line permit(s) and/or certificate(s)

Issue structure location permit(s)

Issue permit(s) to cross state highways

Issue transportation permit(s)

Issue cultural resource clearance, which is required before construction under the National Historic Preservation Act

Issue conditional use permit(s) for line location

a State and local requirements listed are generic in nature; specific requirements will vary by location.

b Generic agency names are listed; specific names of responsible agencies may vary by location.

3. State regulations pertaining to electric transmission line interference with communication facilities (e.g., radio, television);

4. State siting laws regulating overhead transmission lines (e.g., regulated minimum voltage level, regulated minimum line length, regulated in coastal zones);

5. Transmission line compatibility with the existing plans of the state, local governments, and private entities for other developments at or in the vicinity of the proposed route;

6. Permit required for proposed construction that requires an aerial crossing of a lake or stream;

7. Recommended or required electric and magnetic field level standards;

8. State noise standards or ordinances; and

9. State air quality guidelines for ozone concentrations. 


\section{POTENTIAL IMPACT ISSUES AND CORRESPONDING DATA NEEDS}

This chapter discusses potential impact issues that must be considered in the NEPA documentation for a Presidential Permit and identifies the corresponding data needed to evaluate those issues. Section 3.1 focuses on transmission line design factors, and Section 3.2 focuses on the affected environment. The latter section is organized by resource topic and includes information on mitigative measures in addition to discussions of impact issues and data needs.

\subsection{TRANSMISSION LINE DESIGN FACTORS}

\subsubsection{Potential Impact Issues}

Several of the specific impact issues that must be considered and the possible magnitude of those impacts are functions of the design parameters of the proposed transmission line. For example, the spacing and design of support structures will affect the amount of land removed from other productive uses for the life of the line. Also, line design and operational parameters will affect the potential for radio and television interference and the magnitude of electromagnetic fields created in the vicinity of the line. Evaluation of these and other system-specific issues requires compilation of data on the design of the proposed transmission line and associated components.

\subsubsection{Data Needs}

Design parameters for electric transmission lines, along with other pertinent information relating to construction and operation of the transmission line needed to assess environmental impacts, include the following:

- Voltage;

- Conductor type and configuration;

- Support structure design and spacing;

- Land requirements for construction staging areas, substations, or other facilities;

- Routing, including the length, width, and acreage of the proposed rightof-way;

- Areas where construction will require permanent clearing of trees, shrubs, and herbaceous vegetation;

- Changes in topography needed to accommodaie the line; 
- Requirements to remove man-made structures;

- Areas where transmission lines will be placed underground;

- Crossings of highways, railways, water bodies, or areas of archaeological, historical, or recreational interest; and

- Location and design of temporary and permanent access roads.

This information should be described in text and graphical format in the "proposed action" section of the NEPA document. Discretion should be used in determining what design information is appropriate for inclusion. In addition to listing design parameters, the project description should include a discussion of the construction equipment to be used and construction methods to be employed (e.g., special construction techniques to be used in areas of steep terrain or wetlands).

\subsection{GASELINE INFORMATION ON THE AFFECTED ENVIRONMENT}

The following sections describe potential impact issues relative to the affected environment and list the types of baseline environmental information needed to assess the impacts of the construction, operation, and maintenance of a transmission line having the design parameters specified in Section 3.1. If a potential impact is identified, techniques can often be implemented to mitigate that impact so that it is no longer a concern. Often, monitoring is required to identify whether predicted impacts actually occur. The flow diagram in Figure 3.1 illustrates the process involved in addressing potential ecological impacts of transmission line construction and operation.

Separate subsections address the following specific environmental components:

- Air quality and noise;

- Biotic resources;

- Cultural resources;

- Land use, geology, and soils;

- Socioeconomics;

- Water resources;

- Visual resources; and

- Health and safety.

The organization of the subsections follows the general pattern of identifying impact issues, specifying data needed to evaluate those impacts, and discussing potential mitigative 


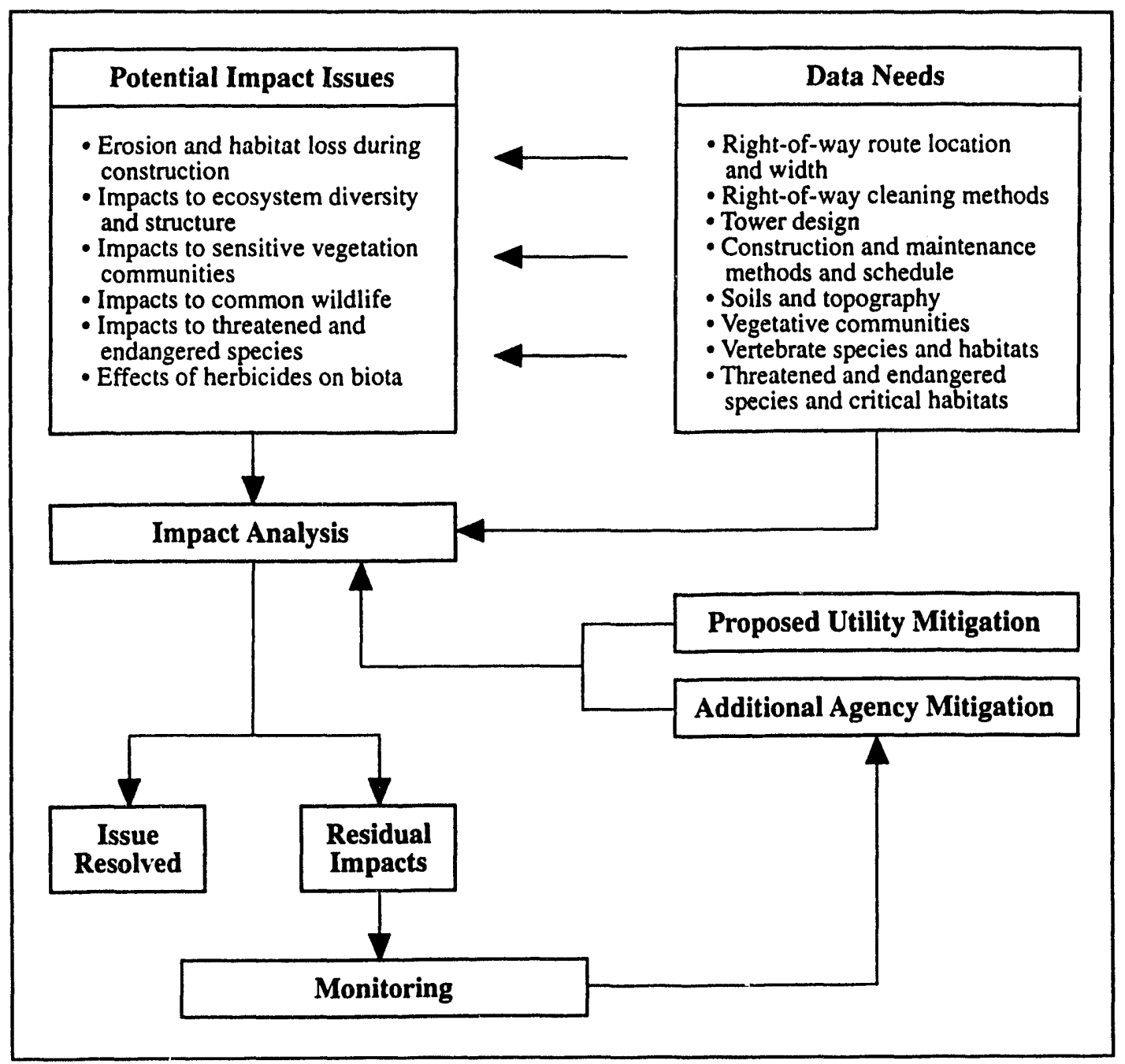

FIGURE 3.1 Generalized Impact Assessment Process with Ecological Resources Used as an Example

measures. Because the discussions are general rather than site- or system-specific, not all of the information would apply to all sites.

\subsubsection{Air Quality and Noise}

\subsubsection{Potential Impact Issues}

\section{Air Quality}

Potential air quality issues related to transmission lines typically include (1) fugitive dust emissions during construction, (2) exhaust emissions of construction equipment and worker vehicles, (3) emissions from burning of cleared vegetation, and (4) ozone generation during transmission line operation. Figure 3.2 lists the impact issues and data required for assessment. 


\begin{tabular}{|c|c|}
\hline Potential Impact Issues & Data Needs \\
\hline $\begin{array}{l}\text { Air Quality } \\
\text { - Construction equipment } \\
\text { exhaust effects on local air } \\
\text { quality } \\
\text { - Fugitive dust emissions } \\
\text { impacts on air quality at } \\
\text { construction sites } \\
\text { - Secondary impacts of } \\
\text { chemicals used in dust } \\
\text { control } \\
\text { - Impacts of ozone produced } \\
\text { during line operation }\end{array}$ & $\begin{array}{l}\text { Air Quality } \\
\text { - Current local concentrations of } \\
\text { pollutants regulated as federal } \\
\text { ambient air quality standards } \\
\text { - Type and number of } \\
\text { construction equipment } \\
\text { - Operating hours of equipment } \\
\text { (i.e., time of day, duration) } \\
\text { - Plans for fugitive dust control } \\
\text { - Local meteorological data } \\
\text { - Temporary revegetation plans } \\
\text { for sites disturbed during } \\
\text { construction } \\
\text { Noise } \\
\text { - Background noise } \\
\text { measurements along the } \\
\text { proposed right-of-way } \\
\text { - Expected levels and existing } \\
\text { sources of impulse noises in the } \\
\text { proposed project vicinity }\end{array}$ \\
\hline
\end{tabular}

FIGURE 3.2 Air Quality and Noise Impact Assessment Issues and Data Needs

\section{Noise}

Construction equipment will be the primary noise source during construction of the transmission line system. Clearing, grading, tower erection, and conductor stringing all require use of heavy equipment generating noise during working hours. Construction of access roads and bridges may also require large equipment typical of a highway construction project. Under certain weather conditions, line operation can generate audible noise (crackling) along the right-of-way. 


\subsubsection{Data Needs}

\section{Air Quality}

Regional and local air quality data should be compiled and presented in summary form within the NEPA document. The fugitive dust impact assessment will be based on known air concentrations of particulates, planned construction activities (e.g., equipment used, duration, locations), and other local or regional emissions sources (such as industrial plants, wood fuel boilers, unpaved/paved roads, and agricultural tilling). Information on local topographic features may be useful in determining areas most likely to be affected by construction emissions.

\section{Noise}

Background noise should be measured during the day and at night to serve as a baseline for determining incremental effects of noise produced during transmission line construction and operation. The locations of nearest residents and other sensitive receptor locations (e.g., schools, hospitals) to the construction sites and data on prevailing wind and local weather conditions are needed to conduct the noise impact analyses. The applicable noise standards that govern construction equipment operation or transmission line operational noise should be evaluated in the impact assessment.

\subsubsection{Mitigative Measures}

\section{Air Quality}

Fugitive dust control methods, such as watering access roads and construction sites, should be described. The use of types and quantities of chemical dust retardants or temporary revegetation practices should be defined in the proposed action section as classes of actions normally considered good engineering practices. Procedures to control exhaust emissions from construction equipment should be defined.

\section{Noise}

The types of mitigative measures for noise might include avoidance of construction work at times that would cause greatest impact to humans and wildlife. For example, the breeding season of sensitive wildlife or wildlife protected by the federal or state government may be avoided by careful scheduling of construction activities. Another mitigative measure would be to avoid conducting noisy construction activities near a church on Sunday morning. 


\subsubsection{Biotic Resources}

\subsubsection{Potential Impact Issues}

Biotic resources include plant communities; wildlife and their habitats; components requiring special evaluation, such as federal- or state-protected species; and wetlands. Biotic resources are evaluated in the course of conducting an ecological impact assessment of transmission line construction, operation, and maintenance. As indicated in Figure 3.3, impact issues related to the ecological assessment include construction effects on vegetation and elimination of wildlife habitat. Specific issues include vegetation clearing, erosion effects to adjacent habitats, wetland impacts from direct disturbance by construction equipment or from erosion, and impacts from tower placement or from existence of the completed line. For the latter issue, the potential for bird collisions with conductors and possible electrocution from contact by large birds of prey are important concerns. Special use of defined habitats, such as wintering areas, or special breeding habitats should be identified in the affected environmental section of the NEPA document.

\section{Wetlands}

Wetland vegetation and soils can be affected during tower construction and conductor stringing activities. Erosion may affect physical conditions in the wetland, thereby altering the plant community composition.

\section{Wildlife}

Commonly encountered impacts to wildlife associated with constructing and operating a transmission line system follow:

- Construction and maintenance along the right-of-way may disturb wildlife species (e.g., white-tailed deer, moose, raptors).

- Wildlife populations may be adversely affected by direct losses of individuals (e.g., mortality, injury) or modification of habitat.

- Wildlife may be affected by improper application of herbicides for rightof-way vegetation control.

- Animals residing within or adjacent to the right-of-way may suffer reduced growth or viability.

- Wildlife species or communities that are listed as endangered, threatened, or sensitive by the state or federal government may be adversely affected by disturbance from transmission line construction or maintenance (see Appendix B - Endangered Species Act of 1973). 


\begin{tabular}{|c|c|}
\hline Potential Impact Issues & Data Needs \\
\hline $\begin{array}{l}\text { - Erosion created during } \\
\text { construction } \\
\text { - Habitat loss/modification during } \\
\text { construction } \\
\text { - Impacts to ecosystem diversity } \\
\text { and structure } \\
\text { - Impacts to sensitive vegetation } \\
\text { communities } \\
\text { - Impacts to common wildlife } \\
\text { - Impacts to threatened and } \\
\text { endangered species } \\
\text { Effects of herbicides on biota } \\
\text { - Impacts to raptors and } \\
\text { waterfowl (such as collisions and } \\
\text { electrocution) } \\
\text { - Clearing of old-growth forests } \\
\text { during construction } \\
\text { Loss of riparian or wetland } \\
\text { vegetation }\end{array}$ & $\begin{array}{l}\text { - Right-of-way route location and } \\
\text { width } \\
\text { - Right-of-way clearing methods } \\
\text { - Tower design } \\
\text { - Construction and maintenance } \\
\text { methods and schedule } \\
\text { - Soils and topography } \\
\text { - Biotic communities } \\
\text { - Threatened and endangered } \\
\text { species } \\
\text { - Wetland locations and types } \\
\text { - Special-use wildlife habitat } \\
\text { - Aquatic ecosystems } \\
\text { - Reclamation and revegetation } \\
\text { of right-of-way } \\
\text { - Right-of-way vegetation control } \\
\text { methods } \\
\text { Access road and bridge } \\
\text { locations }\end{array}$ \\
\hline
\end{tabular}

FIGURE 3.3 Biotic Resources Impact Assessment Issues and Data Needs

- Indirect ecological effects (e.g., increased hunting, off-road vehicle use resulting from creation of access roads and right-of-way) may adversely affect biotic resources.

- Locating a transmission line in an area used by raptors or waterfowl may increase the likelihood of collisions with conductors (Olendorff et al. 1981).

- Electrocution of bald and golden eagles during line operation is most likely to occur along smaller distribution lines that carry between 12 and 69 kilovolts $(\mathrm{kV})$. 


\section{Aquatic Ecology}

Aquatic organisms are likely to be most affected by erosion and sedimentation caused by transmission line construction, access road bridge construction, and physical habitat changes along water bodies where riparian vegetation is cleared. Other potential impacts to aquatic ecosystems may include the following:

- Nontarget aquatic ecosystems may be adversely affected by herbicides used for vegetation control in the right-of-way.

- Indirect ecological effects (e.g., increased fishing) may result from construction of access roads and new right-of-way that provides the public easier access to previously remote areas.

- Critical habitats (e.g., spawning and rearing areas) for fish species listed as sensitive, threatened, or endangered by the state or federal government and important recreational fish species may be affected by increased sedimentation, habitat removal or modification, and fuel spills during the construction period.

- Aquatic species that are listed as endangered, threatened, or sensitive by the state or federal government may be adversely affected by disturbance from transmission line construction or maintenance activities (see Appendix B - Endangered Species Act of 1973).

- Removal of bank vegetation or cover surrounding water resources during construction activities may increase water temperatures. Warmer temperatures might increase productivity in colder streams, but if excessive warming occurs, aquatic species composition could be altered.

- Construction of access roads may reduce stream bank stability in areas of steep terrain, increasing the potential for sedimentation and reducing water quality.

\section{Vegetation}

Vegetation may be removed by clear-cutting or selective cutting at the expected conductor sag point between towers. With selective cutting, some medium to tall shrubs are allowed to remain in the right-of-way in areas adjacent to towers. Depending on the state in which the line occurs, vegetation removal may be by one or both of these methods, and the impacts will depend on the type used. Vegetation is seldom removed in right-of-way corridor segments traversing ravines in areas of rugged terrain because conductor clearance heights 
can readily be met without tree removal. Potential vegetation impact issues that should be addressed in the NEPA document include the following:

- Right-of-way vegetation removal or modification methods before transmission line construction may affect vegetation in areas adjacent to the right-of-way. Plant communities may be damaged by the removal of tall-growing vegetation. Physical changes in the habitat caused by right-of-way vegetation control may adversely affect nontarget vegetation. The growth or viability of plant species within or adjacent to the right-of-way may be reduced.

- Populations of federal- or state-listed endangered, threatened, or sensitive plant species may be adversely affected by disturbance from transmission line construction or maintenance (see Appendix B - Endangered Species Act of 1973).

- Clearing of the right-of-way may necessitate the removal of portions of old-growth forests during construction.

\subsubsection{Data Needs}

The following information is necessary to conduct a preliminary environmental assessment: right-of-way location and width; tower design; construction and maintenance methods and schedules; right-of-way clearing methods; soil and topographic characteristics; vegetative community characteristics; wetland locations and types; wildlife habitat types and locations; aquatic ecosystem characteristics; right-of-way reclamation and revegetation methods; right-of-way vegetation control methods; and access road and bridge locations (see Figure 3.3). Early in the data acquisition process, the utility company should contact the appropriate federal and state agencies to identify their concerns and define issues relative to impacts of project activities on federal- and state-listed endangered or threatened species. The state natural resource management or environmental protection department typically has responsibility for managing or assessing species legally protected by federal and state statutes.

The following discussion considers each component in an ecological assessment and indicates why specific information is necessary.

\section{Wetlands}

Wetland types and boundaries should be shown on project maps. U.S. Fish and Wildlife Service (FWS) wetland inventory maps are a useful source of information in planning the proposed and alternative routes. Jurisdictional wetland delineation along the proposed right-of-way would have to be conducted as part of the data requirements for Clean Water Act Section 404 permit processing. DOE currently requires that wetland maps for proposed and alternative routes be included in an appendix to EIS documents. 


\section{Wildlife}

Information on the important wildlife species should be presented for all native plant communities and other habitats along or adjacent to the proposed right-of-way. Special use areas, such as migration routes between winter and summer habitats, concentrations of den sites, deer wintering yards, and breeding areas, should be identified. The impact analysis will address qualitative impacts associated with losses of both individuals and habitats and, where possible, quantify habitat acreage losses. These losses should be put in the context of similar habitat present in the project area and should indicate the combined significance of the transmission line impacts together with other sources of impact to the same wildlife in the area or region. The latter consideration is addressed in a cumulative impact analysis when appropriate in the scope of the NEPA document.

\section{Aquatic Ecology}

The common and recreationally important fish species in streams traversed by the transmission line should be described in summary format. Species known to be sensitive to sedimentation and temperature changes should be identified. Where the potential for impact from construction activities is high, physical habitat characteristics should be defined. The information could be included in the water resources section of the NEPA document and incorporated by reference into the analysis of impacts of construction activities on aquatic ecosystems.

\section{Vegetation}

The location and extent of various vegetation types along the proposed right-of-way and at substation sites should be described in the affected environment section of the NEPA document. Specific plant communities or vegetation types described in quantitative terms with respect to acreage, dominant tree species, species diversity, etc., can be compared with the acreages at locations of similar types in the vicinity of the right-of-way corridor. The presence of old-growth forests and potential disturbance to such areas are important concerns of the FWS, U.S. Forest Service, Bureau of Land Management, and various state agencies, particularly in the western United States. Locations and acreage likely to be affected should be included in the NEPA document. Other disturbances to vegetation within the right-of-way study area should be described to allow "addition" of the incremental transmission line impacts for purposes of a cumulative impact analysis.

\subsubsection{Mitigative Measures}

Information on mitigative measures is presented to demonstrate how possible impacts can be avoided or minimized through transmission line design, appropriate revegetation, and proper right-of-way vegetation management practices. 


\section{Wetlands}

- If wetland/riparian areas must be crossed by the transmission line, special construction techniques could be employed to minimize impacts. For example, mats or corduroy roads can be used in wetlands. Construction during winter periods when the ground is frozen will reduce wetland impacts.

- Compensation would be necessary if a wetland had to be removed for line construction. Compensation could involve replacing the destroyed wetland with another type of wetland or with a similar type. These determinations would be made in consultation with the FWS and Corps of Engineers. Marble (1992) provides guidance on designing new wetlands. Appropriate federal and state agencies should be consulted to develop a wetlands mitigation plan to be implemented during project construction and operation. Such a plan would identify sensitive resources to be protected and outline specific measures to both create new wetland areas or enhance existing ones to ensure no net loss of wetlands.

- A proactive plan should be implemented to ensure that right-of-way reclamation and revegetation procedures are employed following construction.

\section{Wildlife}

- Ensure appropriate conductor and ground design to eliminate electrocution hazards to large birds of prey. Electrocution of bald eagles during line operation is typical for smaller distribution lines that carry between 12 and $69 \mathrm{kV}$, where the distance from a conductor to an electrical ground or to another conductor is often within a raptor's wingspan. The minimum distance between a conductor and a ground (short-circuit distance) should be about $6 \mathrm{ft}, 8 \mathrm{in}$. (i.e., the vertical distance between the conductor and the structure crossarm). Highervoltage transmission lines pose little electrocution hazard because the separation between the conductors and ground wires is sufficient to prevent contact that would result in electrocution (Olendorff et al. 1981). Platforms could be built as perching or nesting areas on towers above the conductors if no other line routing alternative exists to mitigate electrocution impacts to raptors.

- Consult with appropriate federal and state agencies to obtain information on endangered, threatened, or state-listed species and/or associated habitats that would be affected by the proposed transmission line construction and maintenance. 
- Limit construction activities within priority winter range to avoid significant impacts to wintering deer population during critical periods.

- Install aerial markers along the shield wires at river crossings to increase the visibility of the line and minimize the potential for collisions by bald eagles or other birds that use the river corridors during their daily and migratory movements.

- Avoid bald eagles' winter concentration areas to prevent disturbance of eagles that use these areas and to prevent the removal of important winter habitats.

- Contact the FWS and state wildlife agencies to monitor additional information for listed species (e.g., new locations or habitats for previously listed threatened and endangered species) that could be affected by vegetation management activities. The FWS has provided guidazce for managing rights-of-way to enhance fish and wildlife (U.S. Department of the Interior 1979).

\section{Aquatic Ecology}

- Consult with appropriate federal and state agencies to obtain information on endangered, threatened, or state-listed aquatic species and/or associated habitats that would be affected by construction and maintenance of the proposed transmission line.

- Schedule construction activities during the winter (when fish are not spawning or rearing their young). This mitigative measure need only apply to stream crossings in areas that are known spawning or rearing habitat for important species.

- Follow vegetation removal and soil stabilization guidelines along waterways.

- Route access roads, wherever possible, to use existing bridges and avoid close proximity to streams and wetlands.

- When clearing the right-of-way, leave a buffer strip of vegetation within a few feet of water bodies. Herbicides should not be applied in the buffer zone.

\section{Vegetation}

- As needed, cut tall-growing trees in the right-of-way to prevent flashovers resulting in line outages and fires. 
- Consult with appropriate federal and state agencies to obtain information on endangered, threatened, or state-listed plant species and/or associated habitats that would be affected by construction and maintenance of the proposed transmission line.

- Whenever possible, conduct construction ground patrols and repair activities during periods when surface disturbance would be minimal (e.g., avoid wet periods).

- Conduct vegetation surveys to identify plant species listed as sensitive by the state before transmission line and access road construction activities begin.

- Avoid sensitive plant species during final centerline, access road, and structure siting to minimize impacts to individual plants and/or populations.

- Avoid disturbing old-growth forest areas, thus preventing impacts to the wildlife species dependent on this unique type of ecosystem.

- Consider establishing herbaceous species and shrubs or some low-growing trees that are considered desirable ground cover and valuable wildlife habitat along the right-of-way in the vegetation management and revegetation plan.

- Reduce the potential for accidental herbicide spills from application tanks. Herbicide mixing sites should be located a safe distance from water bodies and wetlands.

- Plant native shrubs to maintain the stream buffer zone in locations where most trees within the zone must be cut to satisfy conductor clearance requirements. Revegetation plans should take the local topographic features into account to maximize shading of surface waters.

\subsubsection{Cultural Resources}

\subsubsection{Potential Impact Issues}

The impacts to cultural resources from an electric transmission line are most likely to occur during construction. Archaeological sites could be destroyed or otherwise affected both by the direct effects of construction activities or by increasing access to areas known to have archaeological resources. Access to remote areas may result from the project, particularly if access roads are left in place after construction is complete. Historic site visitation may also be affected by the transmission line. Fewer visits to historic sites may occur because of visual impacts of the completed line or reduced access to sites during or after 
construction. Potential impact issues and corresponding data needs are illustrated in Figure 3.4.

\subsubsection{Data Needs}

The following information is needed to conduct a cultural resources impact assessment: right-of-way width and location, construction methods, existence of properties on or eligible for the National Register of Historic Places, distance of line to sites listed on or eligible for the National Register of Historic Places, location of access roads, and results of a cultural resource survey of the area. The following actions should be taken in gathering information for evaluating impacts to cultural resources:

- Contact the State Historic Preservation Office to determine if any sites or properties that may be listed on or eligible for the National Register of Historic Places are located in the area of the proposed transmission line.

- Conduct background research on the site through compilation of data on previously recorded prehistoric and historic sites and historic structures and evaluate the potential for occurrence of other cultural resource sites.

- Define an area extending about $0.25 \mathrm{mi}$ on each side of the centerline as the study boundaries of the corridor. Sites identified within and immediately adjacent to the corridor (i.e., within $100 \mathrm{ft}$ ) should be considered in scoping the impact analysis.

- Determine the potential and/or probability of the existence of prehistoric, cultural, and archaeological sites. The assessment should be based on the absence or existence of significant natural resource conditions, which are commonly indicative of areas for historic and prehistoric human activities.

- Conduct cultural resource surveys when required by the State Historic Preservation Office.

- Determine the potential for visual impacts to affect historic properties.

\subsubsection{Mitigative Measures}

The following measures should be considered in project planning to avoid impacts to cultural resources:

- Potential impacts should be avoidable through judicious route selection, compliance with all applicable state and federal procedural requirements 


\begin{tabular}{|c|c|c|}
\hline Potential Impact Issues & & Data Needs \\
\hline $\begin{array}{l}\text { - Adverse, unmitigable effects to historic or } \\
\text { archaeological sites eligible for or listed on the } \\
\text { National Register of Historic Places } \\
\text { - Disturbance of sites of cultural or religious } \\
\text { significance to contemporary Native Americans } \\
\text { (American Indian Religious Freedom Act) } \\
\text { - Increased public access resulting in indirect or } \\
\text { secondary impacts to sites on or eligible for the } \\
\text { National Register } \\
\text { - Visual impacts to sites listed on or eligible for } \\
\text { the National Register, particularly historic } \\
\text { sites whose original settings are seriously } \\
\text { compromised }\end{array}$ & $\leftarrow$ & $\begin{array}{l}\text { - Right-of-way location and } \\
\text { width } \\
\text { - } \text { Construction activities } \\
\text { - } \begin{array}{l}\text { Existence of properties on or } \\
\text { eligible for the National } \\
\text { Register of Historic Places }\end{array} \\
\text { - } \begin{array}{l}\text { Distance of line to sites listed } \\
\text { on or eligible for the National } \\
\text { Register }\end{array} \\
\text { - Location of access roads, road } \\
\text { abandonment plans } \\
\text { - Cultural resource survey }\end{array}$ \\
\hline
\end{tabular}

FIGURE 3.4 Cultural Resources Impact Assessment Issues and Data Needs

and permit restrictions, and completion of field surveys before construction, where appropriate. The State Historic Preservation Office can provide information on procedural requirements applicable to the project.

- A mitigation plan should be prepared and followed throughout construction. The plan may include avoidance of sites, data collection, site-specific control of access and construction, monitoring recommendations, and salvage excavation procedures.

- Cultural features identified within the right-of-way should be flagged to facilitate avoidance during construction.

- If any archaeological artifacts are uncovered during construction, the State Historic Preservation Office should be contacted immediately to evaluate the artifact, and a treatment plan for proper handling and disposition of the artifact should be developed as needed. 


\subsubsection{Land Use}

\subsubsection{Potential Impact Issues}

Land use issues first arise in the process of planning the transmission line route. Impact issues could include potential effects on current and future land uses of the area, increased human access to previously remote areas, and construction effects on prime and unique farmlands. Possible impact issues related to current and future land uses of a typical project area are listed below. Issues and data needs are illustrated in Figure 3.5.

\section{Current Land Use}

- Traditional land use patterns might be modified along the route (i.e., creation of new land uses [such as recreation], disruption of existing uses).

- Construction and maintenance methods or schedules in agricultural areas might cause crop damage in some seasons.

- Presence of the electric transmission line would restrict use of the land within the right-of-way for some other purposes.

- Creation of a new right-of-way and new construction access roads might allow new or easier access by trail bikes and other off-road vehicles, with resulting potential for new or increased loss of privacy, disturbance, and vandalism.

- Construction of a transmission line across major roads or active railroads might delay traffic for short periods.

\section{Future Land Use}

- Land used for the right-of-way may have designated future use.

- Future improvements or expansions could be limited on existing residential, recreational, institutional, commercial, and industrial properties within the transmission line right-of-way.

- If a surface mine or sand or gravel pit were located in the immediate area of an electric transmission line, ongoing or future extraction of the resource around structure bases could be restricted, and the height of equipment used under conductors could be limited. 


\begin{tabular}{|c|c|c|}
\hline Potential Impact Issues & & Data Needs \\
\hline $\begin{array}{l}\text { - Relocation of existing facilities } \\
\text { along right-of-way } \\
\text { - Restricted use of right-of-way } \\
\text { - Agricultural land taken out of } \\
\text { production } \\
\text { - Impacts to prime and unique } \\
\text { farmlands } \\
\text { - Impacts to existing land uses (e.g., } \\
\text { recreation, timber production) } \\
\text { - Modification of traditional land use } \\
\text { patterns }\end{array}$ & & $\begin{array}{l}\text { - } \begin{array}{l}\text { Right-of-way location, length, } \\
\text { width }\end{array} \\
\text { - } \begin{array}{l}\text { Construction method and } \\
\text { schedule }\end{array} \\
\text { - Current land use } \\
\text { - Land use plans } \\
\text { - Distribution of prime and } \\
\text { unique farmlands } \\
\text { - Agricultural production } \\
\text { statistics } \\
\text { - Existing structures within } \\
\text { right-of-way }\end{array}$ \\
\hline
\end{tabular}

FIGURE 3.5 Land Use Impact Assessment Issues and Data Needs

- When transmission lines are placed in common corridors adjacent to existing lines in relatively undeveloped areas, there is a tendency to increase the probability of future impacts to sensitive land uses from future, as yet unidentified, lines.

- Right-of-way location may require removal or relocation of buildings.

\subsubsection{Data Needs}

\section{Land Use}

Information needed to conduct a preliminary environmental assessment includes right-of-way location and width, current land use, and future land use plans for the project area. Current land use types should be presented as percentages for both the county or counties involved and along the proposed right-of-way. Recent changes in land use in the project area should be examined. 


\section{Topography}

The locations of important topographic features along the proposed right-of-way should be identified. The following issues and topics should be evaluated in project planning to determine how topographic characteristics affect right-of-way location and engineering design of structures:

- In some cases long spans and tall structures are preferable, while in other situations short spans and short structures are appropriate.

- Structure height, ravines, topography, and other natural features affect the distance of the conductors from the ground surface.

- Topography influences flexibility during transport, assembly, and erection of the transmission line.

- Construction schedule may be affected by the topography along the proposed right-of-way.

\subsubsection{Mitigative Measures}

\section{Current Land Use Mitigation}

- Where a proposed transmission line would parallel an existing transmission line across cultivated land, developed recreation sites, or commercial and industrial properties, the proposed structures should be located adjacent to existing structures, wherever feasible. This procedure will minimize potential impacts to these sensitive locations by reducing the areas disturbed.

\section{Future Land Use Mitigation}

- Appropriate federal, state, and local agencies should be consulted as necessary to develop construction procedures in accord with site-specific conditions and to further ensure that land use impacts related to the design, construction, and operation of the proposed transmission facilities would be minimized.

- Use of an existing transmission line right-of-way for a proposed line should reduce future impacts to land use in the project region. 


\section{Agricultural Mitigation}

- Wherever possible, placing transmission line structures in agricultural areas should be avoided. Where feasible, the heights of structures should be increased to span croplands.

- To the extent practicable, construction activities should be scheduled to minimize damage to standing crops and limit interference with authorized land use operations.

- If applicable and as necessary, temporary fences, gates, and cattle guards should be installed to control and minimize disturbance to livestock during project construction, operation, and maintenance.

- Residences or other major or inhabited buildings within the right-of-way would have to be removed to comply with electrical safety codes that restrict uses within the right-of-way.

\subsubsection{Geology and Soils}

\subsubsection{Potential Impact Issues}

Potential impact issues and corresponding data needs for geology and soils are illustrated in Figure 3.6.

\section{Geology}

The potential for seismic activity within the geographic region of the project is an importani issue in determining tower type, foundation design, and conductor design. For mountainous terrain expected to experience significant seismic events, construction engineers must determine the potential in a seismic event for tower and conductor structural damage and surface landslides or soil slumping. Long-term tower stability can be a function of the geologic substrate. In areas traversing bogs, for example, anchors must extend $50-100 \mathrm{ft}$ below the surface to ensure tower stability. Some areas will require blasting to create holes for tower footings.

\section{Soils}

Construction of towers and stringing of conductors can adversely affect certain soil types. Soils with a high clay content are susceptible to compaction from use of heavy equipment. Steep slopes are particularly susceptible to surface and gully erosion. An area of concern in planning the right-of-way route is the potential impacts of erosion on wetlands and streams in the immediate vicinity of the construction site. 


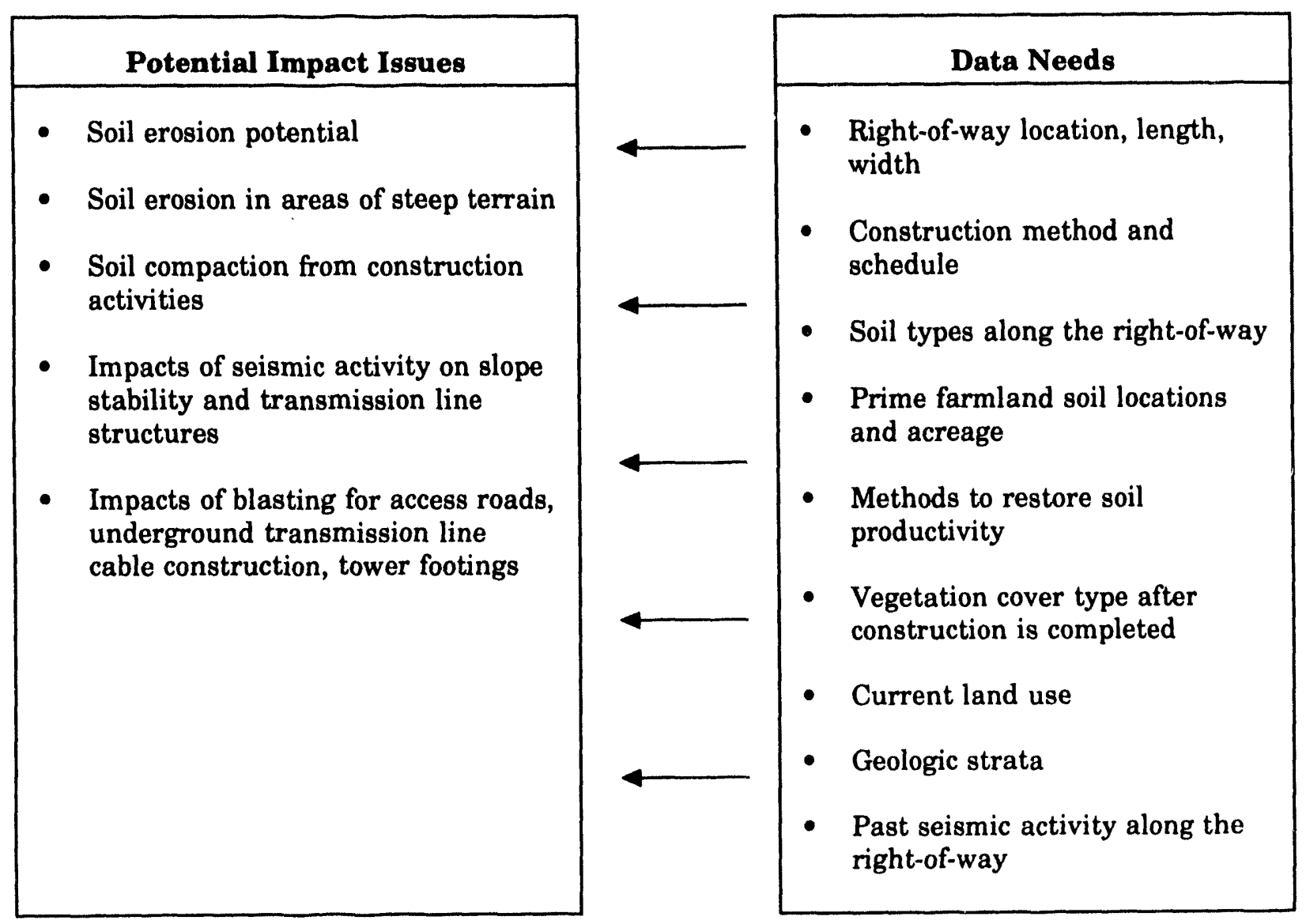

FIGURE 3.6 Geology and Soils Impact Assessment Issues and Data Needs

\subsubsection{Data Needs}

Descriptive information on soil types and slope characteristics is needed for all portions of the proposed right-of-way and areas designated for substation construction. Information on physical properties of soils susceptible to compaction during construction is helpful in deciding how to restore desired soil productivity at disturbed sites. Information on slope characteristics in areas of rugged terrain will help project engineers decide on how and when to best carry out construction tasks and control surface erosion. Soil productivity data, in the form of agricultural yield, are necessary in determining compensation to land owners for crop losses during construction.

Knowledge of the geologic stratigraphy and seismic history of the project area is needed to address potential impacts from blasting for structure footings. The geology of the area should be described to enable assessment of the potential for landslides from earthquakes in areas of steep terrain near the transmission line towers. 


\subsubsection{Mitigative Measures}

\section{Soil Mitigation}

- Implement erosion control measures during construction.

- Use deep plowing and disking equipment on highly compacted soils at the construction site.

- Compensate land owners monetarily for crop production losses due to construction.

- Use riprap or other soil retention methods to stabilize slopes against slumping during some seismic events.

\subsubsection{Socioeconomics}

\subsubsection{Potential Impact Issues}

Socioeconomic considerations of the transmission line project include the added demands of the construction work force on the local and regional infrastructure (e.g., schools, medical services, fire and police protection, roadways). In remote areas where community services are limited, the needs of 30-50 construction workers could place excessive burdens on the local community. On the other hand, beneficial short-term impacts can occur from the expenditure of funds earned by the construction work force and their family members. The impact of the project work force on local housing availability is an issue of importance during project construction.

The value of lands removed from agricultural production due to losses from tower placement must be assessed in the NEPA document. The change in tax rates caused by removal of land from production should be considered in the impact analysis. Potential impacts of the finished transmission line on local property values adjacent to or traversed by the right-of-way should be evaluated.

The change in long-term employment from the project should be addressed if use of the electrical power can be readily quantified and analyzed with respect to new jobs and industrial growth. However, industry growth and secondary impacts associated with such growth are generally beyond the scope of the analysis for a NEPA document (environmental assessment) prepared for a Presidential Permit application (see Appendix A).

Potential impact issues and data needs are highlighted in Figure 3.7. 


\begin{tabular}{|c|c|}
\hline Potential Impact Issues & Data Needs \\
\hline $\begin{array}{l}\text { Demand of construction work force on local } \\
\text { housing } \\
\text { - Economic impacts from expenditure of } \\
\text { wages earned } \\
\text { - Property value declines from presence of } \\
\text { transmission line } \\
\text { - Demand of construction work force on } \\
\text { community services } \\
\text { - Impacts to local schools } \\
\text { - Population density impacts from } \\
\text { transmission line construction, operation, } \\
\text { maintenance } \\
\text { - Employment impacts from transmission line } \\
\text { construction } \\
\text { - Impacts of construction vehicular traffic on } \\
\text { local highways }\end{array}$ & $\begin{array}{l}\text { - } \begin{array}{l}\text { Local and regional housing } \\
\text { statistics }\end{array} \\
\text { - } \\
\text { - School system statistics } \\
\text { Local and regional economic } \\
\text { profile on industry types, jobs, } \\
\text { employment rate, etc. } \\
\text { - } \begin{array}{l}\text { Population breakdown in project } \\
\text { study area }\end{array} \\
\text { - } \begin{array}{l}\text { Community services statistics } \\
\text { - Land use and community master } \\
\text { plans }\end{array} \\
\text { - } \begin{array}{l}\text { Taxation and property value } \\
\text { statistics }\end{array} \\
\text { - Agricultural yield and fair market } \\
\text { prices for products } \\
\text { - } \begin{array}{l}\text { Construction work force size and } \\
\text { construction schedule }\end{array} \\
\text { - Local roadway traffic volumes }\end{array}$ \\
\hline
\end{tabular}

FIGURE 3.7 Socioeconomic Impact Assessment Issues and Data Needs

\subsubsection{Data Needs}

Data on population, housing, community services, and taxing districts and taxation rates must be compiled to evaluate potential impacts of the proposed transmission line system. Data on population characteristics may be needed for several counties in the regional study area. Important population parameters include relative sizes of rural and urban populations, sizes of local towns, population growth or decline rates during the past 5-10 years, and expected changes in population within the next decade. Economic conditions should be described in terms of industry type, major employers, employment numbers, and wages earned. The current mix and availability of housing by type should be described for the multiple county study area. Assessed property values and taxation rates by taxation district should be described for the same multiple county study area as used for the economic characterization. Data should be presented in summarized tabular form. 
Any information available on local and regional highway and road traffic volumes in areas likely to be affected by construction traffic should be included in the NEPA document description of the affected environment.

Data on school system enrollment, capacity, and expected enrollment growth rate are needed to assess the impacts of any workers and families expected to move into the area. Enrollment data and conversations with school system administrators are acceptable for describing current conditions. Medical facilities and police and fire protection services should be defined for the project study area.

\subsubsection{Mitigative Measures}

Land taken out of production will require consideration of monetary compensation to the owners for current losses. The current market values can be used to determine compensation for the land required to be purchased in a fee-simple arrangement. Fair market values for agricultural products and recent yield information (i.e., landowner records, U.S. Department of Agriculture data) can be used to determine monetary compensation for lost production.

Utility companies should evaluate the adequacy of emergency medical transport vehicles and paramedics available to the construction work force and consider financial assistance to current emergency care providers, if necessary.

In cases where local housing is not readily available for the work force, agreements could be reached with owners of available short-term housing in the area to accommodate workers and their families moving to the area. Additional assistance may be necessary if long-term (i.e., permanent) housing is needed. However, in most cases, workers needed to operate and service the transmission line system would reside in the project area.

To the extent possible, construction equipment traffic flow should be scheduled to avoid rush hour commuter traffic periods. Use of traffic guards to limit and control traffic flow can minimize impacts and improve safety at key roadway locations near the construction sites.

\subsubsection{Water Resources}

\subsubsection{Potential Impact Issues}

Potential impacts typically addressed in a NEPA document include construction impacts on water quality where the line traverses or is in the immediate vicinity (i.e., riparian zone) of wetlands, streams, or other water bodies. Clearing of vegetation for the right-of-way may affect water temperature and concentration of suspended solids from increased surface runoff. The potential project impacts relative to state water quality standards must also be addressed. Where access road bridges or culverts are constructed at 
stream crossings, the potential impact to water quality and aquatic organisms should be considered.

Constructing a transmission line in a floodplain may increase the flooding potential downstream of the structures, possibly violating applicable floodplain protection standards (see Section B.12 in Appendix B).

Floodplain surface disturbance associated with the construction of support structures may alter a floodplain storage volume or cause a local increase in the flood stage. Final design for support structures within a floodplain should take into consideration site-specific soil conditions, as well as the elevation of the 100 -year flood and potential for debris being deposited on the structure during a flood. Construction of towers in or adjacent to a wetland may result in vegetation losses and other physical alterations. Figure 3.8 illustrates potential impact issues and data needs.

\subsubsection{Data Needs}

All stream and river crossings should be identified for the entire length of the transmission line right-of-way. Information on streamflow characteristics, existing water quality, and current water supply use by local municipalities is needed for the impact assessment. Groundwater impacts typical for other construction projects are usually negligible for a transmission line project.

Floodplain maps are available from the regional offices of the Corps of Engineers and the Federal Emergency Management Agency. Both the 50- and 100-yr floodplains should be considered in preparing the NEPA document.

\subsubsection{Mitigative Measures}

Measures needed to control erosion and runoff from disturbed sites and thus avoid impact to the water quality of streams or lakes traversed by the line should be included under good engineering practices. Techniques used to control drainage and erosion at surface mines are also useful in certain situations for a transmission line construction site (Vogel 1987). State highway departments and the U.S. Soil Conservation Service can provide suggestions on erosion control measures for the project area.

\subsubsection{Visual Resources}

\subsubsection{Potential Impact Issues}

The visual impacts of an electric transmission line include both short-term construction impacts and long-term operation impacts. Local residents or recreational 


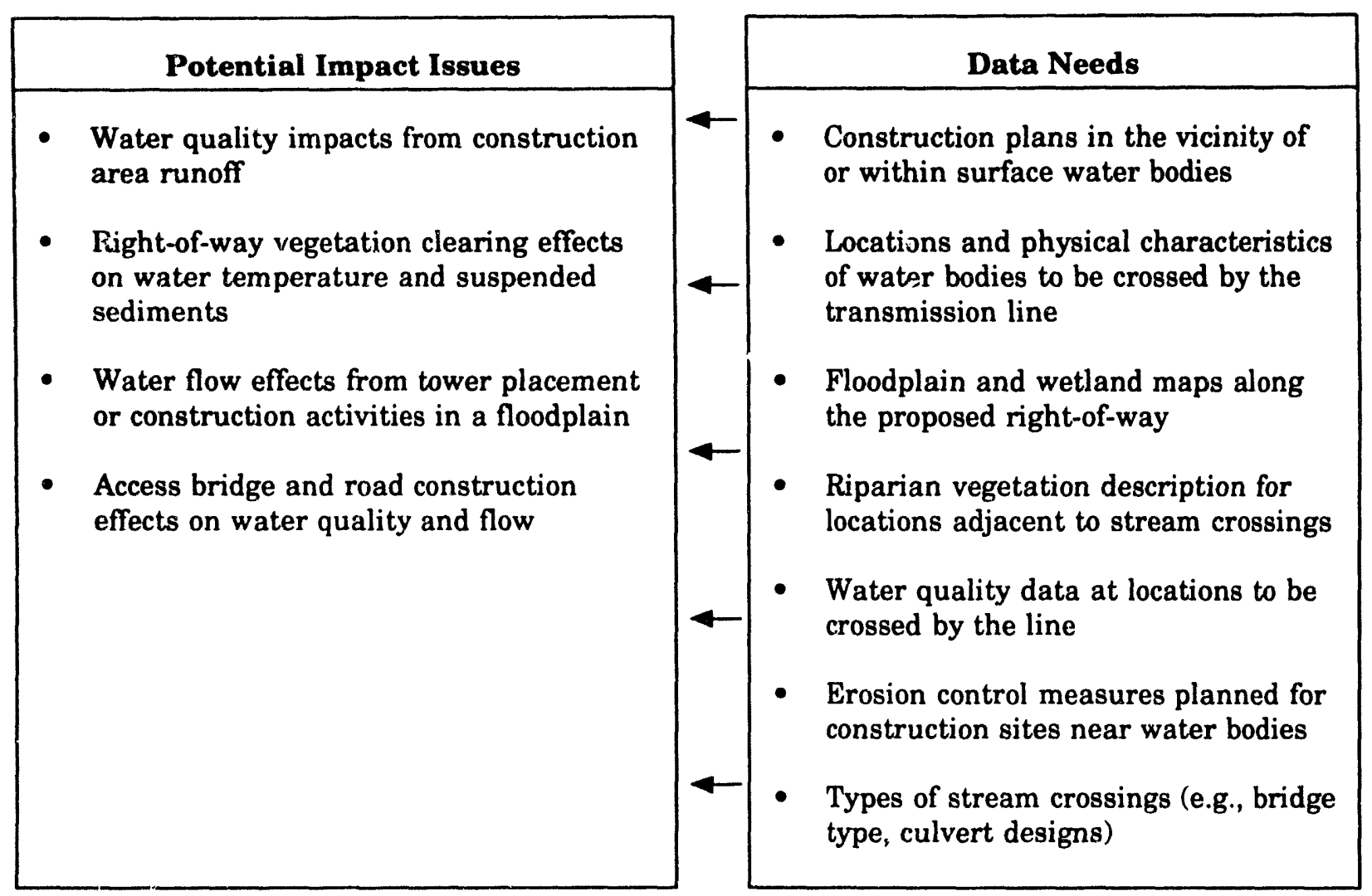

FIGURE 3.8 Water Resources Impact Assessment Issues and Data Needs

visitors to the project area may consider the presence of transmission towers and cleared right-of-way, particularly in locations that represent important viewsheds, to be visually intrusive. Passengers in vehicles traversing the project area may experience visual impacts from right-of-way clearings and towers located near the summits of ridges or mountains. Figure 3.9 illustrates impact issues and data needs.

\subsubsection{Data Needs}

Information needed to conduct a preliminary visual assessment includes right-of-way location and width; tower design and height; type of supporting structure; topography; current land uses; visual quality, classifications, and designations; distance of line visibility; landform and vegetation that would be physically modified; view from sensitive locations (e.g., residents, public viewpoints, recreation areas); naturalness of the land; type and number of existing transmission lines; and existing vegetation and trees that would buffer the line. 


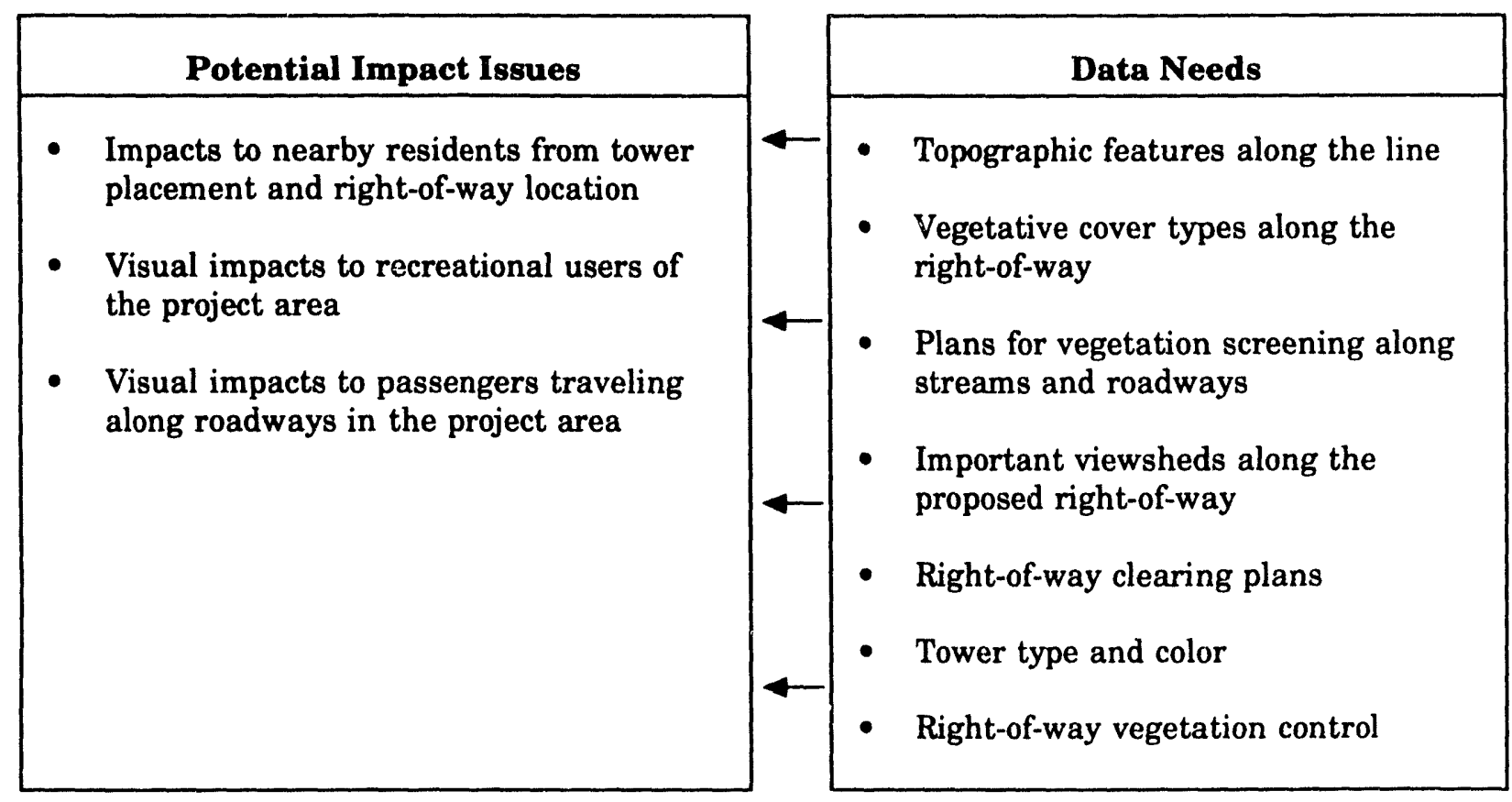

FIGURE 3.9 Visual Resources Impact Assessment Issues and Data Needs

The following items illustrate how the data needs combined with the mitigative measures are used in the preliminary impact assessment.

- Identify existing landforms and vegetation that would have to be modified to accommodate the electric transmission line and how the new structures would blend in with the environment once construction is completed.

- Determine the degree to which this physical contrast would be seen by viewers at sensitive locations.

- Determine the expected degree of visual contrast between the existing environment and the proposed electric transmission line.

- Where feasible, placing structures in visually sensitive areas should be avoided, and structures should be set back at least $50 \mathrm{ft}$ from public roads.

\subsubsection{Mitigative Measures}

- Wood or self-weathering steel support structures can be used in some locations to reduce the visual intrusion of the line. The finish of the selfweathering steel assumes a dull, rusty appearance that blends into the existing surroundings in some locations. 
- Metal towers painted light green or white can often reduce visual impacts in suburban and urban areas.

- When possible, routing the proposed transmission line parallel to an existing right-of-way can reduce the visual impact.

- Avoiding ridge tops and mountain slopes in siting the route can reduce potential visual impacts.

- If the line is constructed near an airport and/or landing strips, marker balls may need to be installed on the static wires to increase visibility, thus minimizing the potential for collisions.

- Where feasible, towers should not be placed in visually sensitive areas. Structures should be set back at least $50 \mathrm{ft}$ from public roads.

\subsubsection{Health and Safety}

\subsubsection{Potential Impact Issues}

Health and safety issues related to the construction, operation, and maintenance of transmission lines routinely center on effects from induced and/or spark discharges, electric and magnetic fields (EMFs), ${ }^{*}$ air ions, audible noise, ozone production, herbicide use for vegetation control, and worker hazards (Figure 3.10). The potential for impacts from several of these health and safety issues would depend on whether the proposed transmission line carried alternating current (AC) or direct current (DC). Typically, the human aspects of these issues are emphasized in the assessment section on health and safety impacts; however, impacts to biota can also be included to avoid the duplication of information that would otherwise occur if this topic were also addressed in the biotic resources sections.

\section{Shock Hazards}

Shocks can result from the passage of electric current through the human or animal body between two points of unequal voltage. Shocks may result from a steady-state flow of current or from a transient, spark discharge.

To assess the potential impacts of shocks, the calculated maximum transient and steady-state currents expected from the line would have to be compared with electric current levels that are known to cause various shock responses (i.e., perceived, annoying, painful to lethal).

* The health issues related to EMF exposure are not addressed in this guidance. 


\begin{tabular}{|c|c|c|}
\hline Potential Impact Issues & & Data Needs \\
\hline $\begin{array}{l}\text { - Shocks from contact with large, } \\
\text { ungrounded metal objects near the line } \\
\text { - Physiological and behavioral } \\
\text { modifications from exposure to air ions } \\
\text { - Annoyance from corona-generated noise } \\
\text { - Herbicide effects on workers, public, } \\
\text { biota } \\
\text { - Worker accidents from construction and } \\
\text { right-of-way or line management } \\
\text { activities } \\
\text { - Radio and television interference }\end{array}$ & & $\begin{array}{l}\text { Maximum transient and steady-state } \\
\text { currents } \\
\text { - Calculated electric and magnetic } \\
\text { fields from centerline to (at least) } \\
\text { several hundred feet from edge of } \\
\text { right-of-way } \\
\text { - Distances of nearest residences and } \\
\text { schools } \\
\text { - Maximum ion densities at ground } \\
\text { level under line (for DC lines) } \\
\text { - Calculated noise at edge of } \\
\text { right-of-way } \\
\text { - Types of herbicides, concentrations } \\
\text { applied, methods of application, } \\
\text { application schedules }\end{array}$ \\
\hline
\end{tabular}

\section{FIGURE 3.10 Health and Safety Impact Issues and Data Needs}

A spark discharge could occur if a grounded human or animal contacts a fence that parallels the line or contacts a large, stationary metal object that is well insulated from the ground.

\section{Herbicide Effects}

The potential for herbicide effects can be assessed by determining safety factors above the no-effects-observed level for wildlife and humans. Modeling studies can consider exposures to herbicides through dermal contact, drinking water, and food consumption.

\section{Worker Hazards}

The construction contractor would be required to comply with all applicable federal and state worker health and safety regulations. Nevertheless, as with all such activities, construction of a transmission line is inherently dangerous. The most likely hazards would be equipment accidents and falls from structures. Once the line is operational, worker hazards would include the potential for falls, electrocution, and injuries from operation of machinery or other activities associated with vegetation and line maintenance operations. 


\section{Radio and Television Interference}

Transmission line operation can interfere with radio and television reception because of corona discharge and gap sparking. The latter is generally caused by defective or loose fittings and can be remedied by routine maintenance. The potential for impacts can be assessed by comparing the radio or television interference to broadcast signal noise for different weather conditions and distances from the centerline.

\subsubsection{Data Needs}

\section{Shock Hazards}

To assess the potential impacts of shocks, the maximum transient and steady-state currents expected from the line would have to be calculated, and information on shock effects that occur at different ranges of these types of currents would have to be obtained.

\section{Air Ion Effects}

Information on maximum ion densities for both polarities under the proposed line and at ground level for different weather conditions would be needed to adequately assess the potential impacts of air ions from the operation of a proposed DC line.

\section{Audible Noise and Ozone Effects}

The following data or information would be needed to assess the potential impacts of audible noise and ozone from the operation of the proposed line:

- Calculated audible noise at the edge of the right-of-way during fair and foul weather.

- Background noise levels in the area of the proposed line and applicable noise-related regulations or recommendations (e.g., EPA recommendations for residential communities).

\section{Herbicide Effects}

Information on types and concentrations of herbicides, method of application, and frequency of application would be needed to adequately assess the potential impacts of herbicides used in vegetation management along the proposed line. 


\section{Worker Hazards}

To assess potential worker hazards, the types of construction and maintenance activities that can cause injury would have to be identified. If available, accident or injury rates for these different types of activities should be provided.

\section{Radio and Television Interference}

To determine radio and television interference, calculated corona-generated radio and television frequency noise levels during different weather conditions would be required for a distance of up to a few hundred feet from the proposed transmission line centerline.

\subsubsection{Mitigative Measures}

The following measures should be considered to mitigate potential health and safety hazards:

- Design the transmission line to meet all requirements of the National Electrical Code (National Fire Protection Association 1989).

- Ground all fences and large metallic structures located near the line.

- To the extent practicable, route the line to avoid hospitals, schools, and single- and multiple-unit dwellings.

- Place colored ball markers on shield wires where the line is located in the vicinity of approach and departure flight paths from an airport.

- Where practicable, align conductors in a manner that minimizes magnetic fields.

- Limit construction work within populated areas to daylight hours.

- Where feasible, design the transmission line with multiple conductor bundles to lower the conductor surface gradient and thus lower corona activity.

- Use only herbicides approved by the state pesticide control board.

- Transport herbicides in strong, leak-proof containers that are properly stored and secured. Herbicide mixing sites should be located a safe distance from water bodies and wetlands and in areas with soils amenable to herbicide adsorption and breakdown.

- Require personnel to wear appropriate protective clothing and respirators when working with herbicides. 
- Do not use herbicides during inclement weather (including excessively windy days).

- Apply herbicides by means of selective basal spray application by workers using hand-held applicators (unless otherwise prescribed by the state pesticide control board).

- Control vegetation in areas near public water supplies, open waters, wetlands, springs, wells, homes, or roadsides by manual removal of undesirable vegetation rather than by applying herbicides.

- Employ a full-time environmental compliance specialist to oversee implementation of spill prevention control and countermeasure plans (e.g., for spilled fuel, herbicides, lubricants). 



\section{APPENDIX A:}

\section{OVERVIEW OF THE NATIONAL ENVIRONMENTAL POLICY ACT AND DOE IMPLEMENTING PROCEDURES}

The National Environmental Policy Act (NEPA) establishes the national policy for federal agencies relating to the protection of the environment. Signed into law on January 1,1970 , its primary role is to require all federal agencies to integrate environmental concerns into their planning and decision-making actions at the earliest possible time. This early integration of environmental concerns includes identification and consideration of environmental issues, evaluation of alternative actions, and identification of appropriate mitigative measures during the development and planning stages of a proposed action. NEPA has two parts: Title I, Declaration of National Environmental Policy, and Title II, Council on Environmental Quality (CEQ).

NEPA and its implementing regulations (CEQ Regulations at 40 Code of Federal Regulations [CFR] 1500-1508) (CEQ 1986) require that federal agencies:

- Include consideration of the environmental effects of proposed actions in their decision-making processes;

- Avoid or minimize adverse effects of proposed actions, and restore and enhance environmental quality as much as possible; and

- Ensure that environmental information is available to the public before decisions are made and before actions are taken.

The CEQ regulations require an agency to begin the preparation of a NEPA analysis as close as possible to the time of proposal development. Specifically, NEPA requires each federal agency to prepare a detailed statement of environmental impact before proceeding with any major action, recommendation, or report on proposals for legislation that may significantly affect the quality of the human environment.

Federal agencies, including the U.S. Department of Energy (DOE), have NEPA implementing procedures that supplement the CEQ regulations. These implementing procedures address how NEPA is to be applied to an agency's particular activities. DOE's implementing procedures, National Environmental Policy Act; Implementing Procedures and Guidelines Revocation; Final Rule and Notice, April 24, 1992 (10 CFR 1021) (DOE 1992b), identify the appropriate level of environmental analysis required for DOE's normal activities.

Actions that typically have a significant impact on the quality of the human environment require a detailed assessment of impacts and preparation of an environmental impact statement (EIS). Actions that may or may not have a significant environmental impact, depending on the situation, are generally analyzed in less detail and are the subject of shorter documents known as environmental assessments (EAs). The text of EISs should normally be less than 150 pages and for proposals of unusual scope or complexity should 
normally be less than 300 pages; EAs are normally 25 to 50 pages long. Preparation of an EA is followed by either a finding of no significant impact (FONSI) or a decision to prepare an EIS. Not all proposed actions result in impacts to the environment. Some proposed projects may fall into a category of actions proven to have little or no effect on the environment and thus normally do not require either an EA or EIS. Actions that do not have, either individually or cumulatively, a significant environmental impact are categorically excluded from further investigation. Figure A.1 depicts NEPA decision-making options and subsequent actions. Table A.1 lists actions relating to electric transmission lines that either typically require an EIS or an EA or are categorically excluded from NEPA documentation.

The process of preparing an EIS begins with a notice of intent published in the Federal Register. This notice contains basic information about the proposal and sets forth the schedule for the agency's scoping process. During the scoping process, members of the public, government agencies, and environmental groups have the opportunity to identify important issues for analysis in an EIS and other environmental review requirements. At the scoping period, as well as in early stages of EIS development, the proponent of the proposed action should provide DOE with information pertinent to project design (e.g., rightof-way width, approximate length of line, transmission line structures, maximum operating voltage), site selection, and line location.

The CEQ regulations state that the primary purpose of an EIS is to serve as an action-forcing device to ensure that the policies and goals defined in NEPA are infused into the programs and actions of the federal government. An EIS provides full and fair discussion of significant environmental issues and informs decision makers and the public of reasonable alternatives that would avoid or minimize adverse impacts or enhance the quality of the human environment. The EIS is a way to assess the environmental impact of the proposed actions; it is not meant to justify decisions already made. Depending on public and agency comments on the draft FIS, the proponent of the proposed action may be required to provide new project information on design, construction, or operation.

An EA has three defined functions: (1) to provide sufficient evidence and analysis for determining whether a proposed action requires the preparation of an EIS or a FONSI; (2) to aid an agency's compliance with NEPA when no EIS is necessary (i.e., to provide an interdisciplinary review of proposed actions, to help identify better alternatives and mitigation measures); and (3) to facilitate preparation of an EIS when one is necessary. The agency may consult with the DOE Office of NEPA Oversight on the scope of the EA before it is prepared. A FONSI is issued if an agency determines, on the basis of an EA, not to prepare an EIS. Contents of an EA are determined case-by-case and depend on the nature of the action. Table A.2 shows the contents of a typical EA, and Table A.3 shows the contents of a typical EIS.

NEPA documents can address three scales of federal activity: national, regional, and site levels. When agencies undertake NEPA analysis at any of these levels, they should 


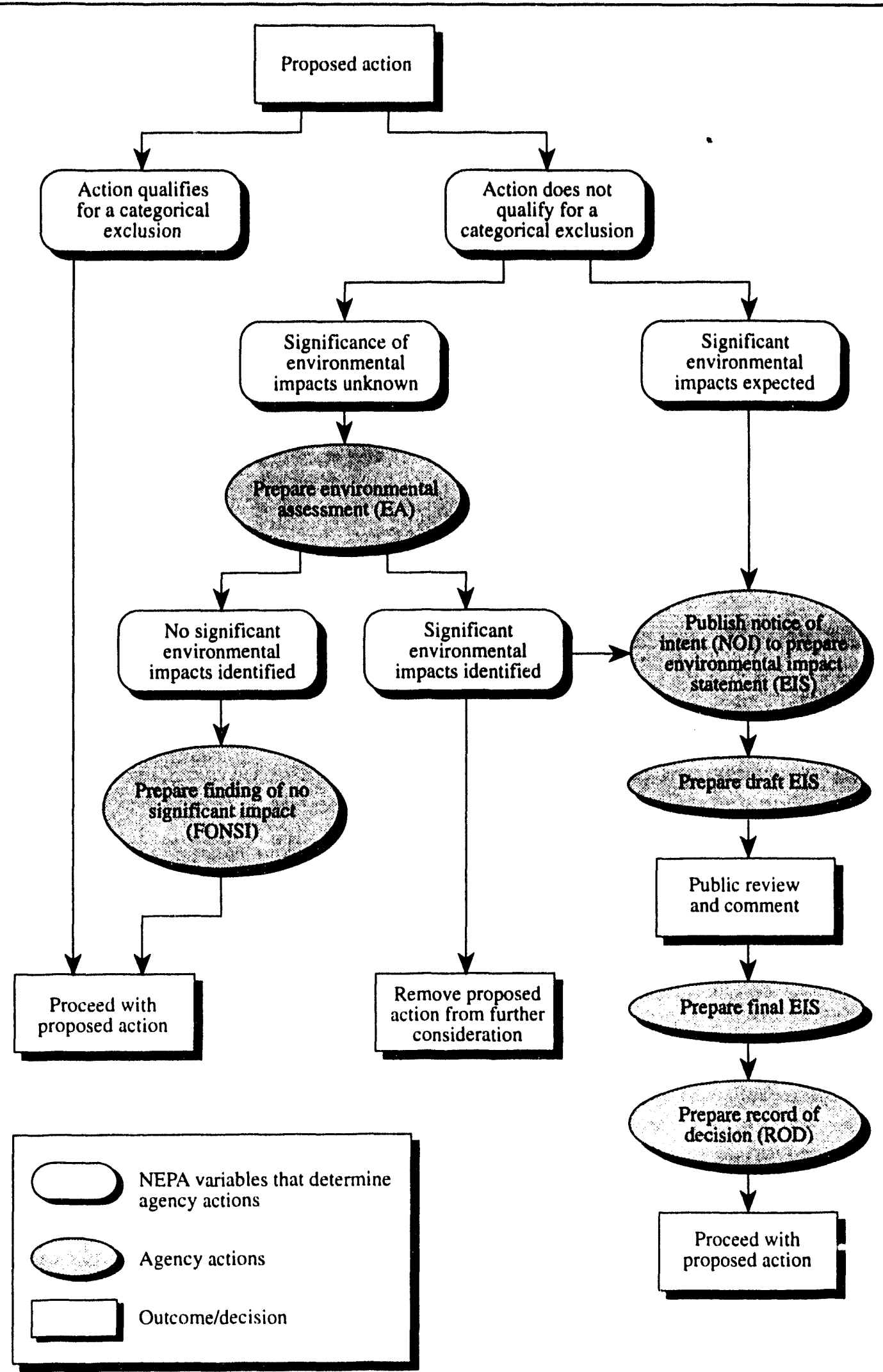

FIGURE A.1 Overview of DOE NEPA Decision-Making and Documentation Process 
TABLE A.1 Examples of DOE Projects that Require Different Levels of NEPA Documentation

\section{Environmental Impact} Statement

Main transmission system additions (e.g., additions of new transmission lines) to a power marketing administration's main transmission grid.

Integrating transmission facilities (e.g., transmission system additions for integrating major new sources of generation into a power marketing administration's main transmission grid).

Establishing and implementing contracts, policies, marketing plans, or allocation plans for periods of five years or longer that involve (1) the addition of major ( $>50$ average megawatts) new generation resources; (2) service to discrete, major new loads (e.g., 10 average megawatts over a 12-month period); and (3) major changes in the operating parameters of power generation resources.
Environmental Assessment

Upgrading an existing transmission line system.

Implementing a power marketing administration systemwide erosion control program.

Establishing and implementing contracts, policies, marketing plans, or power allocation plans for periods of five years or longer that do not involve (1) the addition of major ( $>50$ average megawatts) new generation resources; (2) service to discrete major (10 average megawatts or more over a 12-month period) new loads; or (3) major changes in the operation parameters of power generation resources.
Categorical Exclusion

Emergency repair of transmission lines, including replacement or repair of damaged equipment and the removal and replacement of -downed transmission lines.

Additions or modifications to transmission facilities that do not affect the environment beyond the previously developed facility areas, including tower modifications, changing insulators, replacing poles and crossarms, and similar actions.

Granting or denying requests for multiple use of $\mathrm{DOE}$ transmission line rights-ofway, such as grazing permits and crossing agreements, including electric lines, water lines, and drainage culverts.

Execution of contracts for the short-term or seasonal allocation of excess power resources to customers who can receive these resources over existing transmission lines.

The renewal of existing power contracts in kind.

Source: U.S. Department of Energy (1992b). 
TABLE A.2 Example of an Environmental Assessment Outline for Transmission Line Interconnection Project

Cover Sheet

Foreword

List of Figures

List of Tables

Summary

1 PURPOSE AND NEED

1.1 Introduction

1.2 Project Summary and Purpose

2 ALTERNATIVES

2.1 No-Action Alternative

2.2 Proposed Action

2.2.1 Description of Proposed Route

2.2.2 Applicant's Proposed Mitigation Measures

2.3 Other Route Alternatives

2.3.1 Route Description

2.3.2 Applicant's Proposed Mitigation Measures

3 AFFECTED ENVIRONMENT

3.1 Air Quality

3.2 Geology and Soils

3.3 Surface Water

3.4 Floodplains and Wetlands

3.5 Aquatic Ecology

3.6 Vegetation

3.7 Wildlife

3.8 Existing and Planned Land Use

3.9 Visual Resources

3.10 Cultural Resources

3.11 Socioeconomics and Community Resources

3.12 Transportation and Noise

4 ENVIRONMENTAL CONSEQUENCES

4.1 Proposed Route

4.1.1 Air Quality

4.1.2 Geology and Soils

4.1.3 Surface Water

4.1.4 Floodplains and Wetlands

4.1.5 Aquatic Ecology

4.1.6 Vegetation

4.1.7 Wildlife

4.1.8 Existing and Planned Land Use

4.1.9 Visual Resources

4.1.10 Cultural Resources

4.1.11 Socioeconomics and Community Resources

4.1.12 Transportation and Noise 
TABLE A.2 (Cont.)

4.2 Alternative Routes

4.2.1 Air Quality

4.2.2 Geology and Soils

4.2.3 Surface Water

4.2.4 Floodplains and Wetlands

4.2.5 Aquatic Ecology

4.2.6 Vegetation

4.2.7 Wildlife

4.2.8 Existing and Planned Land Use

4.2.9 Visual Resources

4.2.10 Cultural Resources

4.2.11 Socioeconomics and Community Resources

4.2.12 Transportation and Noise

4.3 Electric and Magnetic Field Effects

4.3.1 Introduction

4.3.2 Corona

4.3.3 Electric Fields

4.3.4 Magnetic Fields

4.3.5 Health Issues

4.4 Worker Health and Safety

4.5 Cumulative Impacts

4.6 Summary

5

consider whether the proposed action is likely to create significant environmental impacts. For any potential impact, determining the extent and nature of analysis under NEPA involves consideration of both the context and intensity of likely effects. Not all proposed actions subject to NEPA procedures will cause significant impacts. However, for actions where nontrivial environmental impacts may occur, the responsible agency should address the impacts of the proposed action, each alternative action, and any mitigation measures. 
TABLE A.3 Example of an EIS Outline for Transmission Line Interconnection Project

Cover Sheet

Foreword

List of Figures

List of Tables

Summary

\section{INTRODUCTION}

1.1 History and Background

1.2 Purpose and Need

1.3 Permit Requirements

1.3.1 Fuel Cost Savings

1.3.2 Capacity Benefits

1.3.3 Reduction in Incremental Energy Losses

1.3.4 Gross Savings

1.3.5 Costs

1.3.6 Net Benefits

1.4 Environmental Effects Abroad of Major Federal Actions

1.5 Environmental Review Process

2 PROPOSED ACTION, ROUTE, AND ALTERNATIVES CONSIDERED

2.1 Description of Proposed Route

2.2 Description of Alternatives to the Interconnection

2.3 Comparison of Alternatives

2.4 Transmission Facilities

2.5 Substations

2.6 Alternatives Considered but Eliminated from Detailed Analysis in the EIS

2.6.1 Energy Supply Alternatives

2.6.2 Transmission System Alternatives

2.6.3 Route Alternatives

2.7 Comparison of Environmental Impacts for the Proposed Route and Alternatives

\section{AFFECTED ENVIRONMENT}

3.1 Proposed Route

3.1.1 Air Quality

3.1.2 Geology and Soils

3.1.3 Surface Water

3.1.4 Floodplains and Wetlands

3.1.5 Aquatic Ecology

3.1.6 Vegetation

3.1.7 Wildlife

3.1.8 Existing and Planned Land Use

3.1.9 Visual Resources

3.1.10 Cultural Resources

3.1.11 Socioeconomics and Community Resources

3.1.12 Transportation and Noise

3.2 Alternatives (same subsections for each route alternative as for the proposed route) 
TABLE A.3 (Cont.)

4 ENVIRONMENTAL CONSEQUENCES

4.1 Proposed Route

4.1.1 Air Quality

4.1.2 Geology and Soils

4.1.3 Surface Water

4.1.4 Floodplains and Wetlands

4.1.5 Aquatic Ecology

4.1.6 Vegetation

4.1.7 Wildlife

4.1.8 Existing and Planned Land Use

4.1.9 Visual Resources

4.1.10 Cultural Resources

4.1.11 Socioeconomics and Community Resources

4.1.12 Transportation and Noise

4.2 Alternr tive Routes/Designs

4.2.1 Air Quality

4.2.2 Geology and Soils

4.2.3 Surface Water

4.2.4 Floodplains and Wetlands

4.2.5 Aquatic Ecology

4.2.6 Vegetation

4.2.7 Wildlife

4.2.8 Existing and Planned Land Use

4.2.9 Visual Resources

4.2.10 Cultural Resources

4.2.11 Socioeconomics and Community Resources

4.2.12 Transportation and Noise

4.3 Electric and Magnetic Field Effects

4.3.1 Introduction

4.3.2 Corona

4.3.3 Electric Fields

4.3.4 Magnetic Fields

4.3.5 Health Issues

4.4 Worker Health and Safety

4.5 Cumulative Impacts

4.6 Additional Mitigation Measures

4.7 No-Action Alternative

4.8 Unavoidable Adverse Impacts

4.9 Relationship between the Local Short-Term Uses of Man's Environment and the Maintenance and Enhancement of Long-Term Productivity

4.10 Irreversible/Irretrievable Commitment of Resources

\section{CONSULTATION AND COORDINATION}

5.1 Public Involvement

5.1 Written Comments Received and Responses

5.3 Public Hearing Comments and Responses 


\section{TABLE A.3 (Cont.)}

\section{References}

Glossary

List of Preparers

Appendixes

- EIS Distribution List (required)

- Biological Assessment for Endangered Species (if necessary)

- Various Environmental Data (if needed to support impact analyses)

Source: Modified from U.S. Department of Energy (1992c). 


\section{APPENDIX B:}

\section{LEGISLATION APPLICABLE TO TRANSMISSION LINE PROJECTS}

Transmission line projects require careful planning to ensure compliance with statutes and regulations pertaining to protection of natural and cultural resources. In the western United States, concerns often arise during the planning phase about potential impacts on species covered by the Endangered Species Act and the Bald and Golden Eagle Protection Act. Assessment of construction impacts requires that the analyst address archaeological and historic sites and areas covered under the American Indian Religious Freedom Act. In some locations, attention to floodplain and wetlands issues is important in transmission route planning. In the Northeast and upper Midwest, transmission line impacts on wetlands require considerable attention by preparers of National Environmental Policy Act (NEPA) documents.

The following sections provide brief summaries of several federal statutes intended to protect natural and cultural resources. Depending on site-specific conditions, not every transmission line interconnection project will affect all resources covered by these acts.

\section{B.1 AMERICAN INDIAN RELIGIOUS FREEDOM ACT OF 1978}

The American Indian Religious Freedom Act establishes a policy for protecting and preserving the inherent right of individual Native Americans to believe, express, and exercise their traditional religions. The act requires federal agencies to consider Indian religious values in undertaking land use projects.

\section{B.2 ARCHAEOLOGICAL RESOURCES PROTECTION ACT}

The Archaeological Resources Protection Act provides a comprehensive framework protecting and regulating the use of archaeological resources on federal and Indian lands. The act prohibits excavation, removal, damage, alteration, or defacement of archaeological resources on federal or Indian lands without a properly issued permit.

\section{B.3 ARCHAEOLOGICAL RECOVERY ACT OF 1960 AS AMENDED BY THE ARCHAEOLOGICAL AND HISTORICAL PRESERVATION ACT OF 1974, 16 USC 469-469C}

The Archaeological Recovery Act, as amended, requires the preservation of archaeological data affected as a result of any federal or federally related land modification activities. Compliance with the Archaeological Recovery Act will be covered under a programmatic agreement for the National Historic Preservation Act. 


\section{B.4 BALD AND GOLDEN EAGLE PROTECTION}

The Bald and Golden Eagle Protection Act makes it unlawful to take, pursue, molest, or disturb American bald and golden eagles, their nests, or their eggs anywhere in the United States. Compliance with this act requires consultations with the U.S. Fisin and Wildlife Service and appropriate state agency to determine if bald or golden eagles, their nests, or their eggs are in the project area. If bald or golden eagles are present, the consultation procedures of the Endangered Species Act will be followed. A permit may be obtained from the U.S. Department of the Interior to relocate eagle nests that interfere with resource development.

\section{B.5 CLEAN AIR ACT}

The Clean Air Act requires the U.S. Environmental Protection Agency (EPA) to set national ambient air quality standards, source performance standards, hazardous air pollution standards, motor vehicle standards, fuel and fuel-additive provisions, and aircraft emission standards. Disturbance of more than 20 acres of land will require a land disturbance permit. The land disturbance permit will require a description of the activity, amount of land disturbed, estimate of the amount of dust released to the atmosphere, and actions to be taken to minimize dust release.

\section{B.6 CLEAN WATER ACT (SECTION 404)}

Section 404 of the Clean Water Act (33 USC 1344) pertains to the discharge of dredged or fill materials into waters of the United States. The National Pollutant Discharge Elimination System (NPDES) permit is administered by the EPA, and activities related to dredge or fill of navigable waters under Section 404 must be reviewed for approval by the Corps of Engineers. Construction sites larger than 5 acres are required to have an NPDES permit to control storm-water runoff. If it is necessary to alter a natural drainage to control storm-water runoff, the Corps of Engineers may have to review the plans to determine if a Section 404 permit is needed.

\section{B.7 COASTAL ZONE MANAGEMENT ACT OF 1972 (AS AMENDED)}

The Coastal Zone Management Act (CZMA) requires that DOE and other federal agencies ensure that all activities conducted in or affecting the coastal zones of states with approved CZMA programs are undertaken in a manner consistent with those programs.

\section{B.8 ENDANGERED SPECIES ACT OF 1973 (16 USC 1531-1543)}

The purpose of the Endangered Species Act (ESA) is to ensure that actions authorized, funded, or carried out by federal agencies do not jeopardize the continued existence of any endangered or threatened species and do not cause the destruction or 
adverse modification of a critical habitat. Compliance with the ESA is achieved through consultations with the U.S. Fish and Wildlife Service and the appropriate state agency. The consultation process generally involves preparation and submittal of a biological assessment (50 CFR 402) to identify any endangered or threatened, or proposed endangered or threatened, species that are likely to be affected by a proposed action. If any endangered species or critical habitat is found to be in potential danger, a programmatic plan designed to protect that species or habitat during project construction and operation usually will be developed.

\section{B.9 FARMILAND PROTECTION POLICY ACT OF 1981}

The purpose of the Farmland Protection Policy Act is to minimize the extent to which federal programs contribute to the unnecessary and irreversible conversion of farmlands to nonagricultural uses. Compliance with this act includes consultation with the Soil Conservation Service and the state or local agency responsible for agricultural lands to determine whether potential exists for site investigation, construction, and operation of a transmission line to affect lands designated either as prime or unique farmlands of state or local importance.

\section{B.10 FEDERAL LAND POLICY AND MANAGEMENT ACT OF 1976}

The Federal Land Policy and Management Act makes provisions for temporary use and rights-of-way on federal lands. Construction of access facilities across federal land requires issuance of a right-of-way permit from the Bureau of Land Management.

\section{B.11 FISH AND WILDLIFE COORDINATION ACT}

The Fish and Wildlife Coordination Act requires federal agencies to consult with or request assistance from the U.S. Department of the Interior, the U.S. Fish and Wildlife Service, and appropriate state wildlife agencies to assess project impacts on wildlife resources and to modify project plans by "justifiable means and measures" to prevent loss or damage of wildlife resources, as well as to provide concurrently for the development and improvement of such resources.

\section{B.12 FLOODPLAIN MANAGEMENT — EXECUTIVE ORDER 11988}

Executive Order 11988 generally discourages federal construction activities in floodplains. An agency is required to evaluate the potential effects of any actions it may take in a floodplain. This process ensures that planning programs and budget requests reflect considerations of flood hazards and floodplain management and prescribes procedures to implement the policies and requirements of this order. 


\section{B.13 MIGRATORY BIRD TREATY ACT}

The Migratory Bird Treaty Act is concerned with the actual killing of migratory birds or the destruction of their eggs and nests.

\section{B.14 NATIONAL HISTORIC PRESERVATION ACT OF 1966}

Historic preservation is defined to include "the protection, rehabilitation, restoration, and reconstruction of districts, sites, buildings, structures, and objects significant to American history, architecture, archaeology, or culture." Section 106 of the National Historic Preservation Act requires federal agencies to "take into account" the effects of their proposed action on properties listed on or eligible for the National Register of Historic Places.

\section{B.15 NOISE CONTROL ACT OF 1972}

The EPA is authorized under the Noise Control Act to develop noise emission standards in four categories, including construction and transportation equipment.

\section{B.16 PRIME AND UNIQUE FARMLANDS}

The purpose of the CEQ memo of August 20,1988, is to alert federal agencies to the opportunity, as well as to the need, for analyzing agricultural land impacts more effectively in the project planning process and under NEPA.

\section{B.17 RESOURCE CONSERVATION AND RECOVERY ACT}

The purpose of the Resource Conservation and Recovery Act is regulation of hazardous wastes generated by operating facilities. Solid wastes and pesticides are regulated, as are liquid wastes.

\section{B.18 RIVERS AND HARBORS ACT}

Section 10 of the Rivers and Harbors Act states that Congress has the power to authorize proposed obstructions to navigable U.S. waters. The same approval cycle also applies to the excavation, filling, or other alteration of certain structures or water bodies in navigable U.S. waters.

\section{B.19 SAFE DRINKING WATER ACT}

State requirements establish design and water quality requirements for potable water from wells. The Safe Drinking Water Act is intended to protect the safety of public water systems. It directs the EPA to promulgated national interim primary drinking water 
standards and to protect the underground sources of drinking water. The act also requires a permit and monitoring for any well providing potable water for more than 25 people for more than 8 hours daily.

\section{B.20 SOIL AND WATER RESOURCES CONSERVATION ACT OF 1977}

The Soil and Water Resources Conservation Act is administered by the Soil Conservation Service, U.S. Department of Agriculture. The act requires an ongoing evaluation of costs and benefits of alternative soil and water conservation practices.

\section{B.21 PROTECTION OF WETLANDS - EXECUTIVE ORDER 11990}

Executive Order 11990 requires that government agencies avoid construction in wetlands unless there are no practical alternatives and unless all practicable measures to minimize harm to wetlands are included in the program.

\section{B.22 WATER RESOURCES PLANNING ACT OF 1965}

The Water Resources Planning Act established a set of university-based research centers throughout the nation that were financed primarily with federal funds administered by the Office of Water Research and Technology in the U.S. Department of the Interior.

\section{B.23 WILD AND SCENIC RIVERS ACT}

The Wild and Scenic Rivers Act preserves and protects selected rivers, or portions of rivers, in the United States. For a river to be eligible for protection under the Wild and Scenic Rivers Act, it must possess some combination of very high scenic, recreational, geological, fish and wildlife, historic, cultural, or similar values. The statute limits the ability of federal agencies such as DOE to license or aid developments affecting rivers designated as potential additions to the Wild and Scenic River System. 


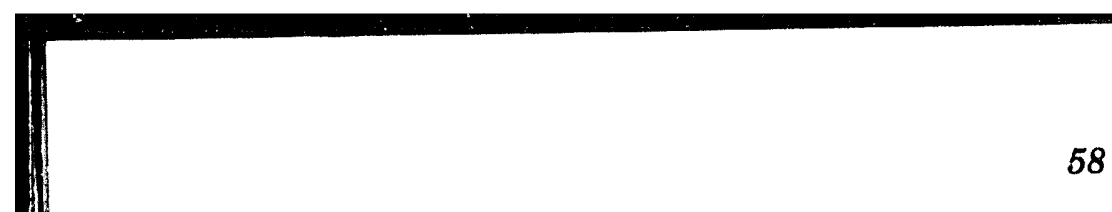

58 


\section{REFERENCES}

Council on Environmental Quality, 1986, Regulations for Implementing the Procedural Provisions of the National Environmental Policy Act, 40 CFR Parts 1500-1508, U.S. Government Printing Office, Washington, D.C.

Gordon, R.E., 1993, Conservation Directory 1993, 38th edition, National Wildlife Federation, Vienna, Va.

Marble, A.D., 1992, A Guide to Wetland Functional Design, Lewis Publishers, Boca Raton, Fla.

National Fire Protection Association, 1989, National Electrical Code, Quincy, Mass.

Olendorff, R.R., et al., 1981, Suggested Practices for Raptor Protection on Power Lines, Raptor Research Report No. 4, Raptor Research Foundation, Inc., University of Minnesota, St. Paul, Minn.

U.S. Department of Energy, 1989, "Organization, Functions, and Authority Delegations," Federal Register 54(52):11436-11438, March 20.

U.S. Department of Energy, 1992a, Washington Water Power/B.C. Hydro Transmission Line Interconnection Project Final Environmental Impact Statement, DOE/EIS-0141, Office of Fuels Programs, Washington, D.C., Oct.

U.S. Department of Energy, 1992b, "National Environmental Policy Act; Implementing Procedures and Guidelines, Revocation; Final Rule and Notice (10 CFR Part 1021)," Federal Register 57(80):15122-15159, April 24.

U.S. Department of Energy, 1992c, Implementation Plan for an Environmental Impact Statement on the Proposed Bangor Hydro-Electric Company's Second 345-kV Transmission Tie Line to New Brunswick, Office of Fuels Programs, Washington, D.C., Jan.

U.S. Department of the Interior, 1979, Management of Transmission Line Rights-of-Way for Fish and Wildlife, Vols. 1 and 2, FWS/OBS-79/22, U.S. Fish and Wildlife Service, Washington, D.C.

Vogel, W.G., 1987, A Manual for Training Reclamation Inspectors in the Fundamentals of Soils and Revegetation, prepared for the Office of Surface Mining and Enforcement by the U.S. Department of Agriculture, Forest Service, Berea, Ky. 


\section{BIBLIOGRAPHY}

Anderson, W.L., 1978, "Waterfowl Collisions with Power Lines at a Coal-Fired Power Plant," Wildlife Society Bulletin 6(2):77-83.

Bealaurier, D.L., et al., 1982, Mitigating the Incidence of Bird Collisions with Transmission Lines, presented at the Third International Symposium on Environmental Concerns in Rights-of-Way Management, San Diego, Calif., Feb. 15-18, 1982.

Boyer, J.C., et al., 1978, The Socioeconomic Impact of Electric Transmission Corridors: A Comparative Analysis, Faculty of Environmental Studies, University of Waterloo, Ontario, Canada, April.

Brown, J.A., 1976, "The Effect of Power Line Structures and Easements of Farm Land Values," Right-of-Way, December 1975-January 1976.

Byrnes, W.R., and H.A. Holt (eds.), 1987, Proceedings, Fourth Symposium on Environmental Concerns in Rights-of-Way Management, Purdue University, Department of Forestry and Natural Resources, West Lafayette, Ind., Oct.

Carnegie Mellon University, 1989, Electric and Magnetic Fields from 60 Hertz Electric Power: What Do We Know about Possible Health Risks? Department of Engineering and Public Policy, Pittsburgh, Penn.

Curtis, W.R., et al., 1980, A Manual for Training Reclamation Inspectors in the Fundamentals of Hydrology, prepared for the Office of Surface Mining and Enforcement by the U.S. Department of Agriculture, Forest Service, Berea, Ky.

Electric Power Research Institute, 1975, Transmission Line Reference Book, $345 \mathrm{kV}$ and Above, 2nd edition, prepared by General Electric Co., Pittsfield, Mass., and Schenectady, N.Y.

Electric Power Research Institute, 1982, Prevention of Golden Eagle Electrocution, EPRI EA-2680, Research Project 1002, prepared by Brigham Young University, Provo, Utah, Oct.

James, B., and B.A. Haak, 1979, Factors Affecting Avian Flight Behavior and Collision Mortality at Transmission Lines, prepared for Bonneville Power Administration, U.S. Department of Energy, Portland, Ore.

Kinnard, W.N., Jr., et al., 1989, The Impact of High-Voltage Overhead Transmission Lines on the Value of Real Property, paper presented at the American Real Estate Society Annual Conference, Arlington, Va., April.

Kitchings, J.T., et al., 1974, Environmental Impacts Associated with Electric Transmission Lines, ORNL-TM-4498, Oak Ridge National Laboratory, Oak Ridge, Tenn., March. 
Meyer, J.R., 1978, Effects of Transmission Lines on Bird Flight Behavior and Collision Mortality, Bonneville Power Administration, Portland, Ore., Sept.

Meyer, J.R., and J.M. Lee, Jr., 1979, Effects of Transmission Lines on Flight Behavior of Waterfowl and Other Birds, presented at the Second Symposium on Environmental Concerns in Right-of-Way Management, University of Michigan, Ann Arbor, Oct. 16-18.

Mountain West Research, Inc., 1982, Electric Transmission Line Effects on Land Values: A Critical Review of the Literature, prepared for the Bonneville Power Administration, Portland, Ore., March.

National Research Council (NRC), 1977, Guidelines for Preparing Environmental Impact Statements on Noise, Washington, D.C.

Olendorff, R.R., and R.N. Lehman, 1986, Raptor Collisions with Utility Lines: An Analysis Using Subjective Field Observations, Final Report, prepared for U.S. Department of the Interior, Feb.

Peterson, A., and E.E. Gross, 1972, Handbook of Noise Measurement, General Radio Company, Concord, Mass., pp. 7-9, 42-45.

Richter, C.F., 1958, Elementary Seismology, W.H. Freeman and Company, San Francisco, Calif.

Shah, K.A., 1979, Review of State/Federal Environmental Regulations Pertaining to the Electrical Effects of Overhead Transmission Lines: 1978, HCP/EV-1802, prepared by Shah \& Associates, Inc., for U.S. Department of Energy, National Technical Information Service, Springfield, Va., Jan.

Thompson, A.R., and E.W. Wood, 1984, Electric Power Plant Environmental Noise Guide, 2nd Edition, prepared by Bolt Beranek and Newman, Inc., for Edison Electric Institute.

Thompson, L.S., 1978, "Transmission Line Wire Strikes: Mitigation through Engineering Design and Habitat Modification," in Proceedings of a Workshop on Impacts of Transmission Lines on Birds in Flight, RWS/OBS-78/48, M.L. Avery (editor), Oak Ridge Associated Universities, Oak Ridge, Tenn., Jan. 31-Feb. 2, published by U.S. Government Printing Office, Washington, D.C., pp. 27-52.

U.S. Army Corps of Engineers, 1987, U.S. Corps of Engineers Wetlands Delineation Manual, Environmental Laboratory, Vicksburg, Miss., Jan.

U.S. Department of Energy, 1987, Final Environmental Impact Statement for New England/Hydro-Quebec +/.450 kV Transmission Line Interconnection - Phase II, Office of Fuels Programs, Washington, D.C. 
U.S. Department of Energy, 1989, Charlie Creek-Belfield Transmission Line Project Final Environmen' Il Impact Statement, DOE/EIS-0134-F, Western Area Power Administration, Billings, Mont.

U.S. Department of Energy, 1989, Electrical and Biological Effects of Transmission Lines: A Review, Bonneville Power Administration Biological Studies Task Team, Portland, Ore., June.

U.S. Department of Energy, 1991, United States/Mexico Electricity Trade Study, DOE/IE-0020P, U.S. Department of Energy and Secretary of Energy of Mexico, March.

U.S. Department of the Interior, 1978, Avian Mortality at Man-Made Structures: An Annotated Bibliography, FWS/OBS-78/58, Fish and Wildlife Service, Washington, D.C.

U.S. Department of the Interior, 1978, Impacts of Transmission Lines on Birds in Flight, FWS/OBS-78/48, M.L. Avery (ed.), Fish and Wildlife Service, Washington, D.C.

U.S. Department of the Interior, 1987, Bird Behavior and Mortality in Relation to Power Lines in Prairie Habitats, prepared by Craig A. Faanes, Fish and Wildlife Service, Fish and Wildlife Technical Report 7, Washington, D.C.

U.S. Environmental Protection Agency, 1974, Information on Levels of Environmental Noise Requisite to Protect Public Health and Welfare with an Adequate Margin of Safety, EPA/550/0-74-004, Arlington, Va.

U.S. Environmental Protection Agency, 1987, PM 10 SIP Development Guidelines, U.S. Environmental Protection Agency, Office of Air Quality Planning and Standards Publication EPA-450/2-86-001, Research Triangle Park, N.C.

U.S. Fish and Wildlife Service, 1980, Workshop on Raptors and Energy Developments, R.P. Howard and J.F. Gore (eds.), Boise, Idaho, Jan.

Ver, I.L., and D.W. Anderson, 1977, Characterization of Transformer Noise Emissions Volume 2: Transformer Environmental Noise Siting Guide, prepared for Empire State Electric Energy Research Corporation, Report 3305, Vol. II, July.

Willard, D.E., et al., 1977, The Impact of a Proposed 500-kV Transmission Line on Waterfowl and Other Birds, prepared for Public Utility Commissioner for the State of Oregon, University of Wisconsin, Madison, June.

Wilson, D.G., 1977, Handbook of Solid Waste Management, Van Nostrand, Reinhold Co., New York, N.Y. 

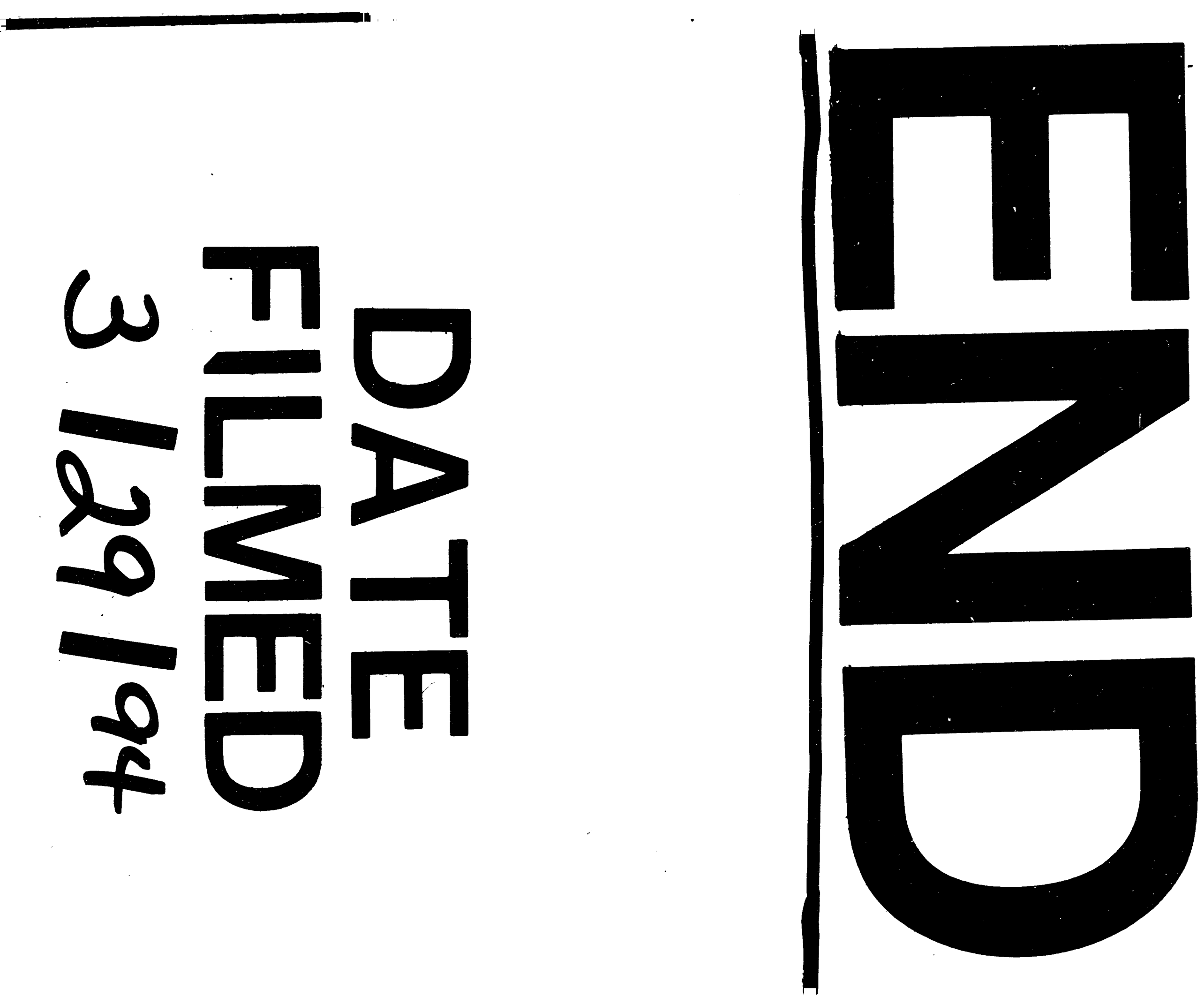

$\lambda$ 


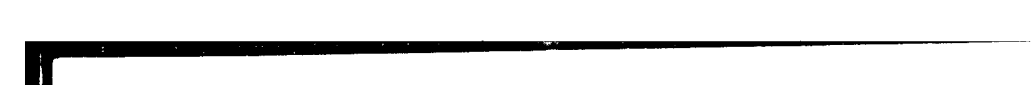

